\title{
Parasitic diseases as a cause of acute abdominal pain: imaging findings
}

\author{
Emre Ünal ${ }^{*} \mathbb{D}$, Sevtap Arslan, Mehmet Ruhi Onur and Erhan Akpinar
}

\begin{abstract}
Acute abdominal pain can be seen in cases with parasitic diseases delivered to emergency departments. The diagnosis of the parasitic disease can be delayed because of the similar clinical signs encountered in other frequently seen causes of acute abdomen. Nevertheless, the features detected in imaging scans can be helpful in the diagnosis. The present study aims to raise awareness about abdominal parasitosis in emergency conditions and also to underline the association between imaging findings and the life cycle of parasites with illustrative cases.
\end{abstract}

Keywords: Abdominal parasitosis, Abdominal emergency, Imaging findings, CT, Acute abdomen

\section{Key points}

- Some types of parasites are endemic for certain locations.

- Immigration and travel are responsible for worldwide cases.

- A parasite may involve a specific organ or migrate through several organs.

- A parasite may induce a cyst formation that could be complicated with rupture, superinfection, or mass effect.

- Clinical and radiological findings may vary for the different types of parasites and their site of involvement.

\section{Background}

Parasitic diseases are common. Although some types of parasites are endemic for certain locations, worldwide cases can be seen due to immigration and travel. A previously published systematic review reported that parasitic diseases resulted in 48.4 million cases annually and 59,724 deaths per year [1]. The diseases caused by most parasites results in significant morbidity and mortality among vulnerable populations. In the same study,

* Correspondence: emreunal.rad@gmail.com

Department of Radiology, School of Medicine, Hacettepe University, 06100 Ankara, Turkey

\section{Springer Open}

researchers emphasize that enteric protozoa, ascariasis, and toxoplasmosis are the most common parasitic diseases; however, the global burden of disease is highest in cysticercosis. Therefore, these data indicate that there is no correlation between the incidence of the parasitic disease and the frequency and severity of symptoms [1]. Parasitic diseases may be transmitted in three different ways as (i) fecal-oral route, (ii) active penetration of the skin by larvae, and (iii) vector arthropods [2]. Infestation affects different parts of the body. Nevertheless, abdominal involvement is seen in the majority of cases. Although the clinical symptoms are usually nonspecific, patients may present with acute abdominal pain due to inflammatory changes in parenchymal organ, bowel walls, bile ducts, and peritoneal surfaces and obstructive changes in bowels and bile ducts. Acute abdominal pain may also result from complications of parasitic involvement such as abscess formation and rupture of focal parasitic cystic lesions. A parasite may be hosted by a specific intraabdominal organ, or may travel among several intraabdominal organs, or may induce a cyst formation that could be complicated with rupture, superinfection, or mass effect. Therefore, clinical and radiological findings may vary for the different types of parasites and also for their site of involvement. The present study aims to raise awareness about abdominal parasitosis that we encountered in our emergency radiology practice. A detailed literature search was also

(c) The Author(s). 2020 Open Access This article is licensed under a Creative Commons Attribution 4.0 International License, which permits use, sharing, adaptation, distribution and reproduction in any medium or format, as long as you give appropriate credit to the original author(s) and the source, provide a link to the Creative Commons licence, and indicate if changes were made. The images or other third party material in this article are included in the article's Creative Commons licence, unless indicated otherwise in a credit line to the material. If material is not included in the article's Creative Commons licence and your intended use is not permitted by statutory regulation or exceeds the permitted use, you will need to obtain permission directly from the copyright holder. To view a copy of this licence, visit http://creativecommons.org/licenses/by/4.0/. 
Table 1 Epidemiologic aspects, route for transmission, and methods used for the definitive diagnosis of the parasitic diseases

\begin{tabular}{|c|c|c|c|c|c|}
\hline Disease & Parasite & Epidemiology & Geographic distribution & $\begin{array}{l}{ }^{1} \text { Hosts/vectors } \\
{ }^{2} \text { Transmission }\end{array}$ & $\begin{array}{l}\text { Final diagnosis (routinely } \\
\text { used method) }\end{array}$ \\
\hline \multirow[t]{4}{*}{$\begin{array}{l}\text { Cystic echinococcosis }^{(c)} \\
{[3-6]}\end{array}$} & E. granulosus $^{(\mathrm{a})}$ & $2-404 / 10,000$ & $\begin{array}{l}\text { High prevalence in Mediterranean } \\
\text { regions, southern and central parts } \\
\text { of Russia, central Asia, China, Australia, } \\
\text { South America and Africa }\end{array}$ & \multirow[t]{4}{*}{$\begin{array}{l}{ }^{1} \text { Definitive hosts (dogs } \\
\text { and foxes) } \\
\text { Intermediate hosts (sheep } \\
\text { and human) } \\
{ }^{2} \text { Ingestion of eggs }\end{array}$} & \multirow{4}{*}{$\begin{array}{l}\text { - Imaging based (primarily } \\
\text { ultrasound findings) } \\
\text { - Serologic assay } \\
\text { - Aspiration of cyst content } \\
\text { during imaging guided } \\
\text { intervention }\end{array}$} \\
\hline & E. multilocularis & $0.2-3400 / 100,000$ & $\begin{array}{l}\text { Asia, Central Europe and the northern } \\
\text { parts of Europe, and North America }\end{array}$ & & \\
\hline & E. oligarthrus & \multirow{2}{*}{$\begin{array}{l}\text { Very rare, } 106 \text { human } \\
\text { cases }\end{array}$} & \multirow[t]{2}{*}{ Central and South America } & & \\
\hline & E. vogeli & & & & \\
\hline \multirow[t]{2}{*}{ Fascioliasis $^{(c)}[3,7]$} & F. hepatica ${ }^{(a)}$ & \multirow[t]{2}{*}{$0.9-6.1 \%$} & $\begin{array}{l}\text { Worldwide, high prevalence in Europe } \\
\text { and America }\end{array}$ & \multirow{2}{*}{$\begin{array}{l}{ }^{1} \text { Intermediate hosts } \\
\text { (Freshwater snails) } \\
\text { Definitive hosts (herbivorous } \\
\text { mammals, including humans) } \\
{ }^{2} \text { Ingestion of watercress or } \\
\text { contaminated water containing } \\
\text { encysted larva }\end{array}$} & \multirow[t]{2}{*}{$\begin{array}{l}\text { - Stool examination } \\
\text { - Serologic assay }\end{array}$} \\
\hline & F. gigantica & & Tropical areas of Asia and Africa & & \\
\hline Ascariasis $^{(c)}[3,8]$ & Ascaris lumbricoides & $8.8-22.3 \%$ & Asia, Africa, and South America & ${ }^{1}$ No intermediate host & Stool examination \\
\hline & & & & $\begin{array}{l}\text { Humans are the only definitive } \\
\text { hosts } \\
2 \text { Ingestion of fecally } \\
\text { contaminated food }\end{array}$ & \\
\hline \multirow[t]{2}{*}{ Toxocariasis $^{(c)}[9]$} & T. canis $^{(\mathrm{a})}$ & \multirow[t]{2}{*}{$0.7-15 \%$} & Worldwide & \multirow{2}{*}{$\begin{array}{l}{ }^{1} \text { Intermediate hosts (rabbit, } \\
\text { lamb, fowl) } \\
\text { Definitive hosts (domestic dogs } \\
\text { and cats). Humans are accidentally } \\
\text { infected intermediate hosts } \\
2 \text { Ingestion of eggs from } \\
\text { contaminated foods }\end{array}$} & \multirow[t]{2}{*}{ Serologic assay } \\
\hline & T. cati & & & & \\
\hline \multirow[t]{3}{*}{$\begin{array}{l}\text { Intestinal taeniasis } \\
\text { 12] }\end{array}$} & T. saginata & \multirow[t]{3}{*}{$0.7-4.9 \%$} & $\begin{array}{l}\text { Sub-Saharan Africa and the } \\
\text { Middle East, Eastern Europe, the } \\
\text { Philippines, and Latin America }\end{array}$ & \multirow{3}{*}{$\begin{array}{l}{ }^{1} \text { Intermediate hosts (pigs for } T \text {. } \\
\text { solium, cattle for } T \text {. saginata) } \\
\text { Definitive hosts (Humans are } \\
\text { the only definitive hosts) } \\
{ }^{2} \text { Ingestion of larvae for taeniasis } \\
\text { and ingestion of eggs for } \\
\text { cysticercosis }\end{array}$} & \multirow[t]{3}{*}{ Stool examination } \\
\hline & T. solium & & $\begin{array}{l}\text { Worldwide; especially in Mexico, } \\
\text { Latin America, West Africa, Russia, } \\
\text { India, Manchuria, and Southeast } \\
\text { Asia }\end{array}$ & & \\
\hline & T. asiatica & & $\begin{array}{l}\text { Taiwan, Korea, Indonesia, Nepal, } \\
\text { Thailand and China }\end{array}$ & & \\
\hline \multirow[t]{3}{*}{ Amoebiasis $^{(c)}[13]$} & E. histolytica ${ }^{(\mathrm{b})}$ & \multirow[t]{3}{*}{$5-42 \%$} & \multirow{3}{*}{$\begin{array}{l}\text { Worldwide. Endemic in developing } \\
\text { parts of Central and South America, } \\
\text { Africa, and Asia }\end{array}$} & \multirow{3}{*}{$\begin{array}{l}{ }^{1} \text { Humans are the principal host } \\
\text { and reservoir } \\
{ }^{2} \text { Ingestion of the cyst from fecally } \\
\text { contaminated food or water }\end{array}$} & \multirow{3}{*}{$\begin{array}{l}\text { - Stool examination } \\
\text { - The real-time PCR (to } \\
\text { identify E. histolytica) }\end{array}$} \\
\hline & E. dispar ${ }^{(a)}$ & & & & \\
\hline & E. moshkovskii & & & & \\
\hline \multirow[t]{4}{*}{ Malaria $^{(c)}[14,15]$} & $\begin{array}{l}\text { P. falciparum } \\
\text { P. vivax }\end{array}$ & \multirow[t]{4}{*}{$5.2-75 \%$} & \multirow[t]{4}{*}{$\begin{array}{l}\text { Tropical Africa, South America, } \\
\text { South-eastern Asia, and Western } \\
\text { Pacific }\end{array}$} & \multirow[t]{4}{*}{$\begin{array}{l}{ }^{1} \text { Vectors (Anopheles mosquitos) } \\
2 \text { Transmitted by infected female } \\
\text { mosquitoes' bites }\end{array}$} & \multirow[t]{4}{*}{$\begin{array}{l}\text { Microscopic examination } \\
\text { of blood }\end{array}$} \\
\hline & P. ovale & & & & \\
\hline & P. malariae & & & & \\
\hline & P. knowlesi & & & & \\
\hline \multirow[t]{2}{*}{$\begin{array}{l}\text { Visceral leishmaniasis } \\
{[16]}\end{array}$} & $\begin{array}{l}\text { Leishmania }^{(a, b)} \\
\text { donovani }\end{array}$ & \multirow[t]{2}{*}{$\begin{array}{l}200,000-400,000 / \text { per } \\
\text { year }\end{array}$} & $\begin{array}{l}\text { Northeast of the Indian subcontinent, } \\
\text { East Africa }\end{array}$ & \multirow{2}{*}{$\begin{array}{l}{ }^{1} \text { Vectors (Phlebotomus sandflies) } \\
2 \text { Transmitted by infected } \\
\text { Phlebotomus sandflies' bites }\end{array}$} & \multirow[t]{2}{*}{$\begin{array}{l}\text { - Bone marrow sampling } \\
\text { - Serological examination }\end{array}$} \\
\hline & Leishmania infantum & & Mediterranean region, Latin America & & \\
\hline Dientamoebiasis $^{(\mathrm{c})}[17]$ & Dientamoeba fragilis & $0.4-42 \%$ & Worldwide & $\begin{array}{l}{ }^{1} \text { Humans are the principal host } \\
{ }^{2} \text { Fecal-oral (hypothetical } \\
\text { transmission via Enterobius } \\
\text { vermicularis eggs) }\end{array}$ & Stool examination \\
\hline Anisakiasis $^{(c)}[18]$ & Anisakis simple & $3 / 1,000,000$ in Japan & $\begin{array}{l}\text { Japan, Korea, Latin America, } \\
\text { and Europe (Scandinavia, The } \\
\text { Netherlands, Spain, France, } \\
\text { Britain). Over } 90 \% \text { of cases } \\
\text { are from Japan }\end{array}$ & $\begin{array}{l}{ }^{1} \text { Intermediate hosts (different } \\
\text { species of crustaceans, fish, or } \\
\text { squid) } \\
\text { Definitive hosts big sea mammals } \\
\text { (whales, dolphins, or seals) } \\
\text { Humans are accidentally infected } \\
\text { intermediate hosts } \\
{ }^{2} \text { Ingestion of raw or undercooked } \\
\text { fish containing larvae of the anisakis } \\
\text { worm }\end{array}$ & $\begin{array}{l}\text { Endoscopy, histopathological } \\
\text { examination }\end{array}$ \\
\hline
\end{tabular}


carried out to be able to summarize the epidemiologic aspects, radiological, clinical, and laboratory findings of these particular parasitic diseases (Tables 1 and 2) [3-19, 67, 74, 78].

\section{Hydatid cyst}

Hydatid disease is a worldwide zoonosis produced by the larval stage of the Echinococcus tapeworm. There are 4 types of Echinococcus infections. E. granulosus is the most common type, whereas E. multilocularis is less common but more invasive, mimicking malignancy [20]. E. vogeli and E. oligarthrus are very rare.

In humans, hydatid disease involves the liver in approximately $75 \%$ of the cases [21]. Although the liver is the most frequent site of involvement, any part of the body may host the hydatid disease. Hepatic hydatid cyst is commonly detected incidentally and patients are asymptomatic in most of the cases. Ultrasonography (US) can be used as a screening method of choice in liver hydatidosis. Gharbi classification system and World Health Organization (WHO) classification system classify the hydatid cysts based on their gray-scale ultrasound appearances. Unilocular or multilocular appearance, anechoic or echogenic content, multivesicular or multiseptated appearance, presence of hydatid sand, daughter cysts, floating membrane, and/or calcified wall are the sonographic features which determine the type of the hydatid cyst in Gharbi's or WHO classification system [18, 22, 23]. Gharbi's and WHO classification systems are helpful to determine to evaluate the cyst activity the appropriate treatment method (medical treatment, percutaneous drainage, or surgical excision) for the hydatid cyst type [22-25]. The sensitivity of computed tomography (CT) in liver hydatidosis is 94\% [20]. Evaluation of cystic component, vascular and biliary tree involvement, and extrahepatic extension may be assessed with magnetic resonance imaging (MRI) [26].

Hepatic hydatid cyst may cause acute abdominal pain due to its complications. The most common complication is the rupture and the most common site of the rupture is the biliary tree [21, 27, 28]. Other sites of the rupture are peritoneal cavity, thoracic cavity, hepatic subcapsular space, hollow viscera, and abdominal wall $[21,27]$. The rupture may cause superinfection and anaphylaxis $[27,28]$. The imaging findings of intrabiliary rupture of the hydatid cyst are structural deformity, loss of spherical shape, dilatation of the intrahepatic bile ducts, and linear filling defects within the biliary tract (Figs. 1 and 2) [21, 27, 28]. Also, air or an air-fluid level within the cyst may be present and this may indicate superinfection (Fig. 3) [28]. Intraperitoneal rupture is a rare complication and may cause peritoneal seeding (Fig. 4) [27, 29]. Superficial, large, and thin-walled hepatic hydatid cysts are most vulnerable to abdominal rupture [28]. The imaging findings of intraperitoneal rupture of the hydatid cyst are focal outward bulging, discontinuity of the cyst wall adjacent to the hepatic capsule, and intraperitoneal fluid collections [21, 27-29]. Also, mural thickening of the bowel loops and peritoneal fat tissue stranding may occur due to the local allergic reactions (Fig. 5). Large hydatid cysts in the liver or other organs may cause acute abdominal symptoms due to mass effect. Alveolar echinococcosis (E. multilocularis) may demonstrate an infiltrative growth pattern and patients' symptoms are correlated with the size of the lesion. Compression of the biliary system may result in acute cholangitis and imaging findings may resemble those seen in liver malignancy (Fig. 6) [30]. Rupture or mass effect may be seen in other abdominal organ involvement (Fig. 7) [31]. In renal hydatid disease, the rupture of the hydatid cyst in the pelvicalyceal system is a rare complication (Fig. 8). Other rare complications of abdominal hydatid cyst (disease) are portal hypertension, portal vein thrombosis, and Budd-Chiari syndrome due to mass effect on the portal and hepatic veins [28].

\section{Fascioliasis}

Fascioliasis is an important disease caused by Fasciola hepatica and Fasciola gigantica. F. hepatica is the most common type. Freshwater snail species are the intermediate hosts for fasciola parasites while many herbivorous mammals including humans are the definitive host [32]. Fasciola parasites develop into adult flukes in the bile ducts of infected mammals, which transfer immature Fasciola eggs through their feces [36].

The infection in humans begins when watercress or contaminated water containing encysted larva are ingested. The larvae reach the liver after penetrating the duodenal wall, migrating through the peritoneal cavity and penetrating the Glisson's capsule. The flukes then migrate through the liver parenchyma to the bile ducts and gallbladder which are their permanent residence. The migratory larval and resting adult stages correspond to two clinical stages of the life cycle, called the hepatic and biliary stages [34, 35]. Common symptoms of the hepatic phase are urticaria, right upper quadrant pain, and fever. The biliary phase is usually accompanied by intermittent right upper quadrant pain, with or without cholangitis or cholestasis [36].

The migration process causes multiple microabscesses in the liver. The findings of the migration process become visible on CT as a "tunnel-like tract" from the entry site at the Glisson's capsule deep to the parenchyma and clustered small necrotic cavities arranged in serpentine fashion are seen as "caves" [34-37]. "Tunnels and caves" sign is very characteristic for fascioliasis (Figs. 9 and 10). Subcapsular hemorrhage-effusion, thickening, and enhancement of the focal liver capsule may occur due to penetration of the Glisson's capsule by larva [36, 38]. 
Table 2 Parasitosis and affected abdominal organs. Associated radiological, clinical, and laboratory findings

\begin{tabular}{|c|c|c|}
\hline \multicolumn{2}{|c|}{ Disease type } & Imaging findings \\
\hline \multicolumn{3}{|c|}{ Cystic echinococcosis $^{a}[2,3,19-31]$} \\
\hline \multirow[t]{4}{*}{ Liver } & Perihepatic rupture & $\begin{array}{l}\text { - Fluid collection through the course of } \\
\text { cyst's content } \\
\text { - Mural thickening of the bowel loops } \\
\text { and fat tissue } \\
\text { stranding adjacent to cyst contents } \\
\text { - Focal outward bulging, discontinuity } \\
\text { of the cyst wall }\end{array}$ \\
\hline & Biliary rupture & $\begin{array}{l}\text { - Structural deformity, loss of spherical } \\
\text { shape of the cyst } \\
\text { - Dilatation of the intrahepatic bile ducts } \\
\text { with linear filling defects within the } \\
\text { biliary tract } \\
\text { - Lipid-fluid level due to bile } \\
\text { - Air or an air-fluid level within the cyst if } \\
\text { superinfection is present }\end{array}$ \\
\hline & Vascular invasion & $\begin{array}{l}\text { - Dilatation of the affected vein (most } \\
\text { commonly hepatic veins) } \\
\text { - Total occlusion or linear filling defects } \\
\text { within the lumen } \\
\text { - Parenchymal hemodynamic change at } \\
\text { vascular territory }\end{array}$ \\
\hline & Biliary compression & $\begin{array}{l}\text { - Dilatation of the intrahepatic bile ducts } \\
\text { without linear filling defects; however, } \\
\text { increased echogenicity/decreased T2 } \\
\text { signal could be seen due to within the } \\
\text { biliary tract. Dilatation of the } \\
\text { intrahepatic bile ducts, enhancement } \\
\text { of intrahepatic biliary duct, } \\
\text { parenchymal changes (increased } \\
\text { signal intensity on T2-weighted } \\
\text { images, segmental parenchymal } \\
\text { enhancement) }\end{array}$ \\
\hline \multirow[t]{3}{*}{ Kidney } & Perirenal rupture & $\begin{array}{l}\text { - Fluid collection through the course of } \\
\text { cyst's content } \\
\text { - Focal outward bulging, discontinuity } \\
\text { of the cyst wall }\end{array}$ \\
\hline & $\begin{array}{l}\text { Pelvicalyceal system } \\
\text { rupture }\end{array}$ & $\begin{array}{l}\text { - Structural deformity, loss of spherical } \\
\text { shape of the cyst } \\
\text { - Hydroureteronephrosis, pyonephrosis } \\
\text { may accompany } \\
\text { - Filling defects within the pelvicalyceal } \\
\text { system } \\
\text { - Urinoma may accompany in case of } \\
\text { pelvicalyceal system rupture }\end{array}$ \\
\hline & $\begin{array}{l}\text { Pelvicalyceal system } \\
\text { compression }\end{array}$ & $\begin{array}{l}\text { - Hydroureteronephrosis without filling } \\
\text { defects } \\
\text { - Urinary dilatation is seen above the } \\
\text { level of compression }\end{array}$ \\
\hline
\end{tabular}

Fascioliasis $^{\mathrm{a}}[2,3,32-43]$

Liver Hepatic stage

Clinical presentation

Lab findings

RUQ or generalized abdominal pain, fever, nausea and vomiting, urticaria, and fatal anaphylaxis

UU pain, jaundice, pruritus, fever, nausea and vomiting, anaphylactic reaction

RUQ pain, dyspnea and chest pain in case of pulmonary embolism

$-R \cup Q$, jaundice, pruritus -Fever, nausea and vomiting less common compared to biliary rupture

Flank pain, fever, nausea and vomiting, urticaria, and fatal anaphylaxis

Flank pain, fever, nausea and vomiting, urticaria, and fatal anaphylaxis

Flank pain, fever, nausea and vomiting, urticaria, and fatal anaphylaxis

RUQ pain, urticaria, right upper quadrant pain and fever, fatigue
Leukocytosis, elevated CRP

(C reactive protein), eosinophilia, increase in serum aspartate transaminase (AST) and alanine aminotransferase (ALT) levels

Leukocytosis, elevated CRP, eosinophilia, elevated serum AST, ALT, gamma-glutamyl transferase (GGT), alkaline phosphatase (ALP), bilirubin, and amylase

Leukocytosis, eosinophilia, abnormal liver function tests and, hypoxemia and hypocapnia/ hypercapnia in case of pulmonary embolism

Eosinophilia, elevated ALP, GGT, and bilirubin
Leukocytosis, elevated CRP, eosinophilia, high serum blood urea nitrogen (BUN), and creatinine

Eosinophilia, elevated BUN, and creatinine

Leukocytosis, eosinophilia, elevated liver enzymes caves" sign

- Subcapsular hemorrhage-effusion, focal liver capsule thickening and enhancement

- Periportal lymphadenopathy, rarely portal vein thrombosis and wedgeshaped hemorrhagic infarction

- Splenomegaly may accompany

- Dilated biliary ducts, periportal thickening

- Floating particles in the biliary system

- Cholecystitis and/or pancreatitis may accompany
RUQ pain, pain could be disseminated in case of pancreatitis, jaundice, fever, nausea, diarrhea, pruritus
Leukocytosis, eosinophilia, elevated liver enzymes, hyperbilirubinemia, and elevated pancreatic enzymes in case of pancreatitis 
Table 2 Parasitosis and affected abdominal organs. Associated radiological, clinical, and laboratory findings (Continued)

\begin{tabular}{|c|c|c|}
\hline Disease type & Imaging findings & Clinical presentation \\
\hline \multicolumn{3}{|l|}{ Ascariasis $^{a}[2,3,44-49]$} \\
\hline Gastrointestinal system (GIS) & $\begin{array}{l}\text {-Tubular structure within the lumen of } \\
\text { stomach or bowel, associated fat tissue } \\
\text { stranding } \\
\text { - Dilated bowels in case of intestinal } \\
\text { obstruction } \\
\text { - Rarely, intraabdominal free fluid, gas, } \\
\text { and/or fluid collection in case of GIS } \\
\text { perforation } \\
\text { - Inflamed and distended appendix } \\
\text { vermiformis }\end{array}$ & $\begin{array}{l}\text { Abdominal distension, dyspepsia, } \\
\text { nausea and vomiting in case of } \\
\text { GIS obstruction, generalized } \\
\text { abdominal pain fever and sepsis } \\
\text { in case of GIS perforation, RLQ } \\
\text { pain in case of acute appendicitis }\end{array}$ \\
\hline Liver & $\begin{array}{l}\text { - Areas of decreased attenuation on CT, } \\
\text { altered echogenicity on US due to } \\
\text { parenchymal involvement } \\
\text { - Filling defects within the biliary tree or } \\
\text { gallbladder } \\
\text { - Biliary dilatation, periportal inflammation } \\
\text { - Gallbladder wall thickening and distention } \\
\text { - Parenchymal or perihepatic abscess }\end{array}$ & $\begin{array}{l}\text { RUQ pain, fatigue, fever, jaundice } \\
\text { and pruritus in case of biliary } \\
\text { dilatation, MURPHY sign positivity } \\
\text { in case of acute cholecystitis, } \\
\text { septic status can be seen in } \\
\text { case of gallbladder perforation } \\
\text { or liver abscess }\end{array}$ \\
\hline Pancreas & $\begin{array}{l}\text { - Thickening of pancreas, peripancreatic } \\
\text { fat tissue stranding and fluid collection } \\
\text { may accompany }\end{array}$ & $\begin{array}{l}\text { Epigastric pain and acute } \\
\text { pancreatitis can be the sole } \\
\text { presentation or be seen following } \\
\text { biliary involvement }\end{array}$ \\
\hline
\end{tabular}

Toxocariasis $^{\mathrm{a}}[2,46-49]$

Liver

Taeniasis $^{a}[2,18,50-56]$

Gastrointestinal system (GIS)

Liver

Pancreas

Amoebiasis $^{a}[44,57-59]$

Colon

Liver
- Multiple, ill-defined, oval shaped, small lesions $(<2 \mathrm{~cm})$ in parenchyma

- Lesions may coalescence on follow-up

- Splenomegaly may accompany

-Tubular structure within the lumen of stomach or bowel, associated fat tissue stranding

- Dilated bowels in case of intestinal obstruction

- Rarely, intraabdominal free fluid, gas and/or fluid collection in case of GIS perforation

- Inflamed and distended appendix vermiformis

- Filling defects within the biliary tree or gallbladder

- Biliary dilatation, periportal inflammation

- Thickening of pancreas, peripancreatic fat tissue stranding and fluid collection may accompany

- Colonic wall thickening, mucosal edema and increased mucosal enhancement (primarily ascending colon)

- Rarely, intraabdominal free fluid, gas and/or fluid collection in case of colonic perforation

- Parenchymal loculated fluid collection (abscess), air or an air-fluid level can be seen within the collection.

- Perihepatic fluid and right-sided pleural effusion may accompany
- Gallbladder wall thickening and distention
Anemia, leukocytosis, eosinophilia

Anemia, leukocytosis, eosinophilia, and elevated liver tests including bilirubin

Leukocytosis, eosinophilia, elevated pancreatic enzymes, mild hyperbilirubinemia, high ALP and GGT levels

RUQ pain, fatigue, fever, nausea and vomiting

Leukocytosis, eosinophilia, mildly elevated liver enzymes

Abdominal distension, dyspepsia, nausea and vomiting in case of GIS obstruction, generalized abdominal pain fever and sepsis in case of GIS perforation, RLQ pain in case of acute appendicitis

Leukocytosis, eosinophilia, anemia

RUQ pain, fatigue, fever, jaundice and pruritus in case of biliary dilatation, MURPHY sign positivity in case of acute cholecystitis, septic status can be seen in case of gallbladder perforation

Epigastric pain and acute pancreatitis can be the sole presentation or be seen following biliary involvement

Bloody diarrhea, tenesmus, fever, and abdominal pain. Generalized abdominal pain and sepsis in case of colonic perforation

RUQ pain, fever, colonic symptoms may accompany, sepsis in case of diffuse liver abscesses
Leukocytosis, eosinophilia, hyperbilirubinemia and elevated liver enzymes

Leukocytosis, eosinophilia, elevated pancreatic and liver enzymes

Leukocytosis, anemia

Leukocytosis without eosinophilia, anemia, elevated liver enzymes, high erythrocyte sedimentation rate and CRP 
Table 2 Parasitosis and affected abdominal organs. Associated radiological, clinical, and laboratory findings (Continued)

\begin{tabular}{|c|c|c|c|}
\hline Disease type & Imaging findings & Clinical presentation & Lab findings \\
\hline \multicolumn{4}{|l|}{ Malaria $^{a}[14,60-66]$} \\
\hline Liver & $\begin{array}{l}\text { - Hepatomegaly, periportal edema, } \\
\text { perihepatic or intraabdominal ascites } \\
\text { - Gallbladder wall thickening and distention } \\
\text { due to acalculous cholecystitis }\end{array}$ & $\begin{array}{l}\text { RUQ pain, fatigue and fever, } \\
\text { MURPHY sign positivity in } \\
\text { case of acute cholecystitis }\end{array}$ & $\begin{array}{l}\text { Anemia, thrombocytopenia, } \\
\text { leukocytosis, mild } \\
\text { hyperbilirubinemia, } \\
\text { mildly elevated liver enzymes }\end{array}$ \\
\hline Spleen & $\begin{array}{l}\text { - Areas of decreased attenuation on CT, } \\
\text { altered echogenicity on US due to } \\
\text { infarction, splenomegaly } \\
\text { - Parenchymal or perisplenic hemorrhage/ } \\
\text { hematoma in case of spontaneous splenic } \\
\text { rupture }\end{array}$ & $\begin{array}{l}\text { LUQ pain } \\
\text { Rapid clinical deterioration } \\
\text { tachycardia and hemorrhagic } \\
\text { shock in case of splenic rupture }\end{array}$ & \\
\hline Gastrointestinal system (GIS) & $\begin{array}{l}\text { - Dilated bowels in case of intestinal } \\
\text { obstruction } \\
\text { - Rarely, intraabdominal free fluid, gas, } \\
\text { and/or fluid collection in case of GIS } \\
\text { perforation }\end{array}$ & $\begin{array}{l}\text { Nausea and vomiting in case } \\
\text { of GIS obstruction, generalized } \\
\text { abdominal pain fever and sepsis } \\
\text { in case of GIS perforation }\end{array}$ & \\
\hline Pancreas & $\begin{array}{l}\text { - Thickening of pancreas, peripancreatic } \\
\text { fat tissue stranding and fluid collection } \\
\text { may accompany }\end{array}$ & $\begin{array}{l}\text { Epigastric pain and symptoms } \\
\text { related to acute pancreatitis }\end{array}$ & $\begin{array}{l}\text { Anemia, thrombocytopenia, } \\
\text { leukocytosis, hyperbilirubinemia, } \\
\text { elevated liver and pancreatic } \\
\text { enzymes }\end{array}$ \\
\hline \multicolumn{4}{|c|}{ Visceral leishmaniasis $^{a}[16,67-72]$} \\
\hline Liver & $\begin{array}{l}\text { - Hepatomegaly, ascites, right-sided } \\
\text { pleural effusion } \\
\text { - Nodular shaped focal parenchymal } \\
\text { lesions }\end{array}$ & RUQ pain, fatigue and fever, & $\begin{array}{l}\text { Pancytopenia, elevated CRP, } \\
\text { hypergammaglobulinemia }\end{array}$ \\
\hline Spleen & $\begin{array}{l}\text { - Splenomegaly, ascites, left sided } \\
\text { pleural effusion } \\
\text { - Nodular shaped focal parenchymal } \\
\text { lesions } \\
\text { - Parenchymal or perisplenic hemorrhage/ } \\
\text { hematoma in case of spontaneous splenic } \\
\text { rupture }\end{array}$ & $\begin{array}{l}\text { LUQ pain, fatigue and fever, } \\
\text { rapid clinical deterioration } \\
\text { tachycardia, and hemorrhagic } \\
\text { shock in case of splenic rupture }\end{array}$ & \\
\hline Lymph nodes & $\begin{array}{l}\text { - Enlarged and heterogeneous lymph } \\
\text { nodes, central cystic changes can be } \\
\text { seen in case of necrosis }\end{array}$ & $\begin{array}{l}\text { Painful and palpable peripherally } \\
\text { located lymphadenopathy }\end{array}$ & \\
\hline \multicolumn{4}{|l|}{ Dientamoebiasis $^{\mathrm{a}}[17,73]$} \\
\hline Gastrointestinal system (GIS) & $\begin{array}{l}\text { - Bowel wall thickening, mucosal edema, } \\
\text { associated intra-abdominal free fluid } \\
\text { - Dilated bowels in case of intestinal } \\
\text { obstruction }\end{array}$ & $\begin{array}{l}\text { Abdominal pain, diarrhea, } \\
\text { anorexia }\end{array}$ & Leukocytosis, rarely eosinophilia \\
\hline Liver & $\begin{array}{l}\text { - Periportal fat tissue stranding and/or } \\
\text { edema }\end{array}$ & RUQ or epigastric pain, fever & \\
\hline \multicolumn{4}{|l|}{ Anisakiasis $^{a}[74-77]$} \\
\hline Gastrointestinal system (GIS) & $\begin{array}{l}\text { - Severe submucosal edema of the } \\
\text { involved gastrointestinal area, adjacent } \\
\text { fat tissue stranding, enlargement of } \\
\text { lymph nodes, intraabdominal free } \\
\text { fluid may accompany. Rarely intestinal } \\
\text { obstruction due to intussusception }\end{array}$ & $\begin{array}{l}\text { Abdominal pain, nausea, } \\
\text { vomiting, diarrhea, signs of } \\
\text { peritoneal irritation } \\
\text { lleus/intestinal obstruction } \\
\text { with or without intussusception }\end{array}$ & Leukocytosis \\
\hline
\end{tabular}

${ }^{\text {aReferences }}$

Wedge-shaped hemorrhagic infarction in the periphery of the liver was reported as a result of an experimental study on hepatobiliary fascioliasis [39]. A case presenting portal vein thrombosis has also been reported [40]. Periportal lymphadenopathy is a frequent and helpful finding which can be encountered in both hepatic and biliary stage [38].
In the biliary stage, adult flukes in the extrahepatic bile ducts and gallbladder cause biliary epithelial hyperplasia, hypertrophy, and partially or complete biliary obstruction [34-36]. The obstruction causes acute abdominal pain due to complications such as cholestasis, cholecystitis, cholangitis, and pancreatitis [41-43]. Imaging features of acute abdominal pain due to biliary obstruction 


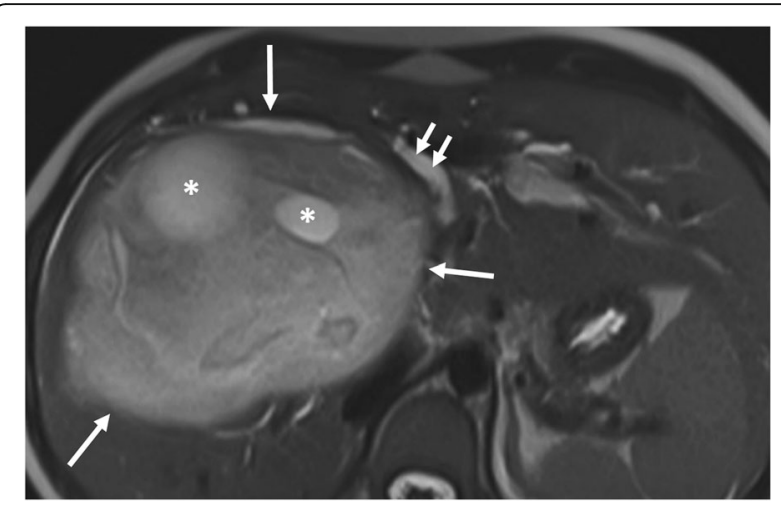

Fig 1. A 16-year-old girl was admitted to the emergency department with a 1-week history of pruritus, jaundice, and fever. Axial T2-weighted MR-image shows the imaging findings of intrabiliary rupture of a hydatid cyst (long arrows). Floating membrane within the dilated bile duct (short white arrows) and daughter cysts (asterisks) are also noted. Serological tests for $E$. granulosus were positive.

by adult flukes include dilated biliary ducts, linear echogenic floating particles in the biliary system on ultrasonography (US), and irregular thickening of bile duct walls, contrast enhancement of duct walls, and intermediate signal filling defects in the dilated ducts on T2-weighted MR images. Imaging features of accompanying microabscesses in the liver parenchyma such as heterogeneous echotexture due to focal small hypo- or hyperechoic lesions on US and round or oval clustered hypodense lesions with peripheral contrast enhancement on CT and MRI may be helpful in the differential diagnosis [34, 35, $38,79]$. A large cavitary lesion may occur rarely as a result of reinvasion of the hepatic parenchyma by an adult worm and rupture of the bile duct. As a rare complication of fascioliasis, acute hemobilia related to the bleeding ulcer in the bile duct may be observed [36].

\section{Ascariasis}

Ascaris lumbricoides is the most common and the largest roundworm parasite of the human intestine [2]. A. lumbricoides are transmitted through the ingestion of contaminated food. After eggs are dissolved in the stomach to initiate larva formation, the larvae reach the caecum and migrate through the liver via penetrating portal vein branches. They reach hepatic veins via hepatic sinusoids and finally, the right heart and lungs are involved. They travel to bronchi and trachea and may be seen in sputum at this stage. When sputum is swallowed again, they reach the gastrointestinal system where they become adult worms [44].

Patients with ascariasis are asymptomatic or present with nonspecific abdominal symptoms. Acute abdominal pain may occur due to complications [2]. Small bowel obstruction is an expected complication in the massive infestation. Massive worm aggregates may cause bowel infarction and gangrene. The worms have a predilection for the orifices and the ampulla of Vater is frequently involved. Thus, biliary and pancreatic complications are also common [45]. Biliary colic, acute cholecystitis, recurrent cholangitis, liver abscess, and acute pancreatitis are related complications [45, 46]. Rarely the worm causes gastrointestinal perforation [47]. On sonography, the roundworm may be seen as single or multiple, long, linear, and thick echogenic strips without acoustic shadowing [48]. A central, longitudinal anechoic tube between two parallel echogenic lines, known as "triple line sign," represents the digestive tract of the Ascaris worm $[46,49]$. US may reveal the movement of the worm during real-time scanning. Acute intestinal obstruction secondary to ascariasis may present on $\mathrm{CT}$ as dilated bowel loops and elongated or rounded filling defects in the contrast filled lumen of the bowel [48]. Ascaris worms manifest as relatively hyperattenuating tubular structures surrounded by less attenuated bile in the setting of bile duct obstruction [48]. Acute pancreatitis caused by Ascaris worms presents on CT as diffusely dilated pancreatic duct and peripancreatic edema. (Fig. 11).

\section{Toxocariasis}

Toxocariasis is the infection in the human host with Toxocara canis or Toxocara cati. Their definitive hosts are the domestic dog and cat. Humans (especially children) are accidentally infected hosts when they ingest the eggs from contaminated foods. The larvae hatch in the small intestine, penetrate the wall, and migrate to all organs via the bloodstream (visceral larva migrans) [80]. The liver, lungs, central nervous system, and eyes are the most affected organs. Cardiac involvement may rarely be encountered (Fig. 12). Tissue damage is largely dependent upon eosinophilic inflammation as a response of the host immune system to the dead larvae [80].

Clinically, most of the patients are asymptomatic. Heavy infection can cause fever, abdominal pain, general weakness, weight loss, and pulmonary and neurological symptoms [81, 82]. Liver involvement appears as small, oval, multiple hypoechoic lesions on US [81, 82]. On $\mathrm{CT}$, the most common imaging finding of the hepatic toxocariasis is multiple, ill-defined, oval or sometimes angular or trapezoid in shape, low-attenuating nodules along the portal vein branches that are measured less than $2 \mathrm{~cm}$, best seen on the portal venous phase. An enhancing rim may be seen on arterial phase images. When the infection becomes severe, the small lesions fuse to form large lesions, some of which are crossed by portal vein branches (Fig. 12) [81, 82]. Toxocariasis appears as single or multiple lesions with low signal intensity on T1-weighted images and high signal intensity on T2-weighted images. Portal phase images after 

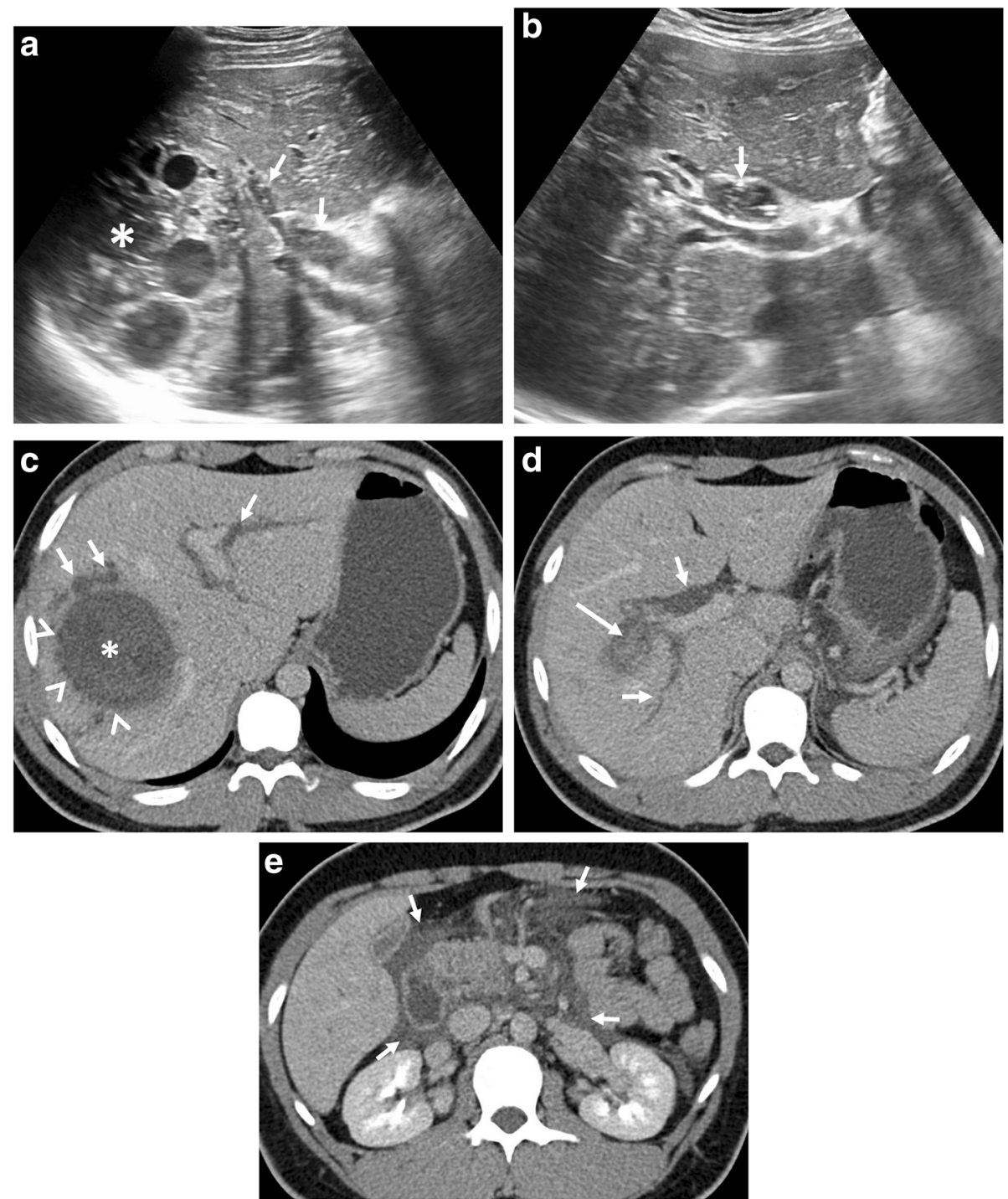

Fig. 2. A 21-year-old man presented to the emergency department with a 1-week history of upper abdominal pain, pruritus, and jaundice. Laboratory tests revealed increased levels of serum amylase, lipase, and acute phase reactants. Serological tests for E. granulosus were positive. a, b Axial gray-scale US images demonstrate the imaging findings of intrabiliary rupture of a hydatid cyst (asterisk). The right main bile duct and choledochal duct are dilated due to cyst contents (arrows, a, and b). c-e Axial contrast-enhanced CT images reveal hydatid cyst (asterisk) and associated wall irregularity (arrowheads) due to intrabiliary rupture. Note biliary dilatation (short arrows, $\mathbf{c}$ and $\mathbf{d}$ ) and also increased attenuation levels of the right main bile duct due to cyst contents (long arrow). CT image at the level of pancreas demonstrates peripancreatic fat tissue stranding (arrows, e) compatible with acute pancreatitis

intravenous (IV) gadolinium administration are the most helpful method to demonstrate poorly defined lowsignal intensity lesions. Concomitant lung lesions may also be seen in severe infection [82]. Cardiac involvement including myocarditis, pericarditis, and Loeffler's endocarditis may be encountered in rare cases with Toxocariasis [83].

\section{Intestinal taeniasis}

Human taeniasis is a parasitic infection caused by three tapeworm species, Taenia saginata, Taenia solium, and
Taenia asiatica. Humans are the only definitive hosts for these Taenia tapeworms. Humans become infected with tapeworms when they eat raw or undercooked beef or pork containing infective cysticerci [50]. Intestinal taeniasis is acquired by ingesting T. solium or T.saginata larvae, whereas ingestion of $T$. solium eggs causes cysticercosis [50]. Following Taenia solium ingestion, the embryos may penetrate the bowel wall and enter portal circulation. Afterward, they reach distal capillaries (cysticercosis) of richly perfused tissues (central nervous system, skeletal muscle, eyes, and subcutaneous tissue) $[18,50]$. 


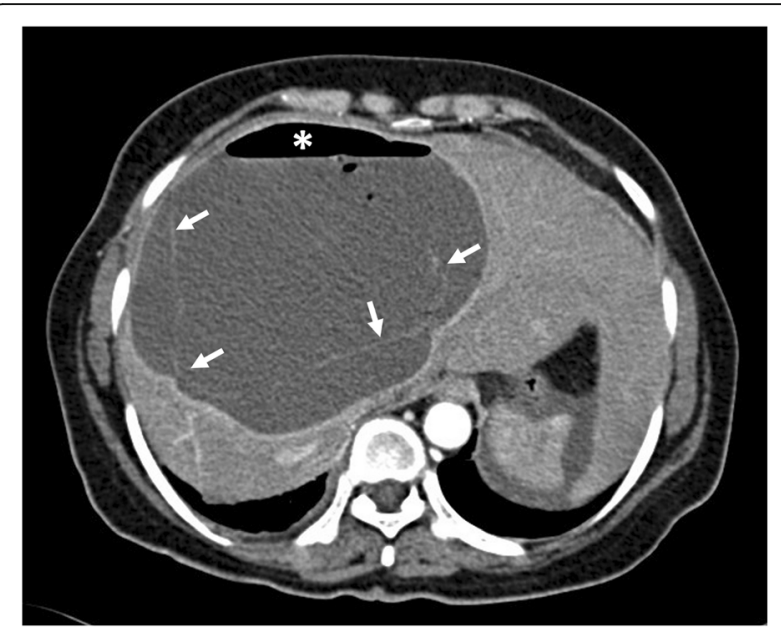

Fig. 3 A 62-year-old woman presented to the emergency department with fever, fatigue, and right upper quadrant pain. The patient had a previous history of liver hydatid disease which was stable for 1-year of follow-up. Axial contrast-enhanced CT image shows a liver abscess. Floating membranes (arrows) and associated air-fluid level (asterisk) within the cyst indicating superinfection of a liver hydatid cyst. Culture test following percutaneous drainage of the cyst revealed Streptococcus anginosus infection

Most people with tapeworm infections have no symptoms or mild symptoms. But rare complications such as intestinal obstruction, intestinal perforation, gallbladder perforation, acute pancreatitis, acute appendicitis, and acute cholecystitis may cause acute abdominal pain [51-55]. Adult worms in gallbladder lumen, bile ducts, and

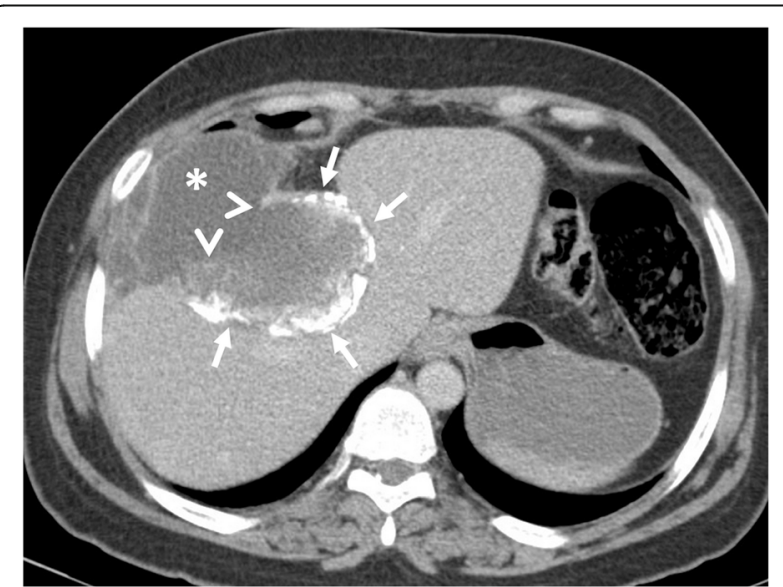

Fig. 4 A 30-year-old woman was admitted to the emergency department with right upper quadrant pain. Axial contrast-enhanced CT image demonstrates calcified hydatid cyst (arrows) rupture through the perihepatic space. A fluid collection containing cyst content (asterisks) was found adjacent to the hepatic capsule due to the loss of integrity of the cyst wall (arrowheads). Surgical findings confirmed the rupture of the hydatid cyst into the perihepatic space
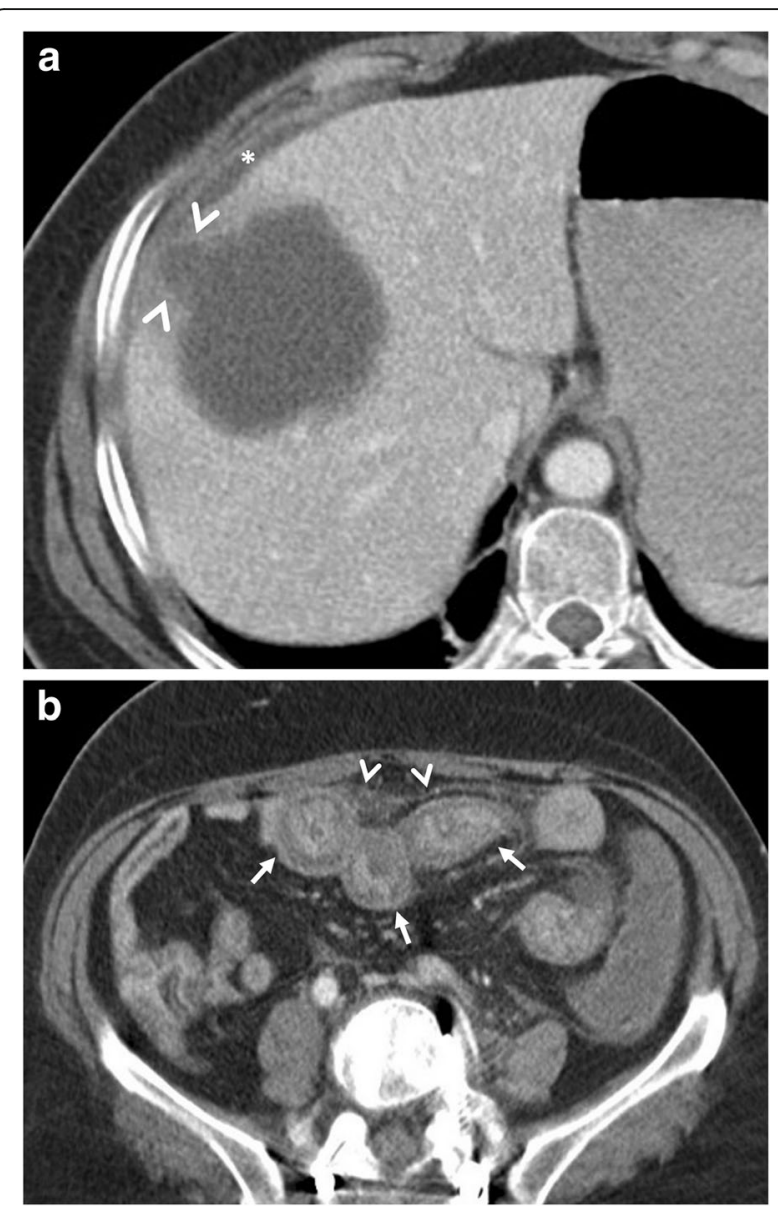

Fig. 5 A 16-year-old girl was admitted to the emergency department with an acute onset of right upper quadrant pain and fever. a Axial contrast-enhanced CT image demonstrates the imaging findings of intraperitoneal rupture of a hydatid cyst. Focal outward bulging found at the lateral wall of the cyst indicates the site of rupture (arrowheads, a). Mild fluid collection adjacent to the hepatic capsule was also noted (asterisk). b Axial CT image from lower abdomen shows mural thickening of the jejunal loops (arrows) and adjacent fat tissue stranding (arrowheads) indicating the local allergic reaction of bowel wall secondary to ruptured hydatid cyst. Surgical findings confirmed the intraperitoneal rupture of the hydatid cyst

pancreatic duct become visible as linear hyperechoic materials on US with dilatation of the involved ducts [53]. Intestinal taeniasis appears as a fine, tubular structure with hyperechoic walls in the intestinal lumen on US (Fig. 15). Taenia worms cause double-reflective, ribbon-like echo in the lumen of the bowels (Fig. 13) [56]. MRCP images demonstrate hypointense linear structures within the dilated intra- and extrahepatic bile ducts in biliary system involvement [59]. The presence of abundant free fluid and free air on imaging studies suggests perforation of luminal organs involved by the parasite $[51,52]$. 

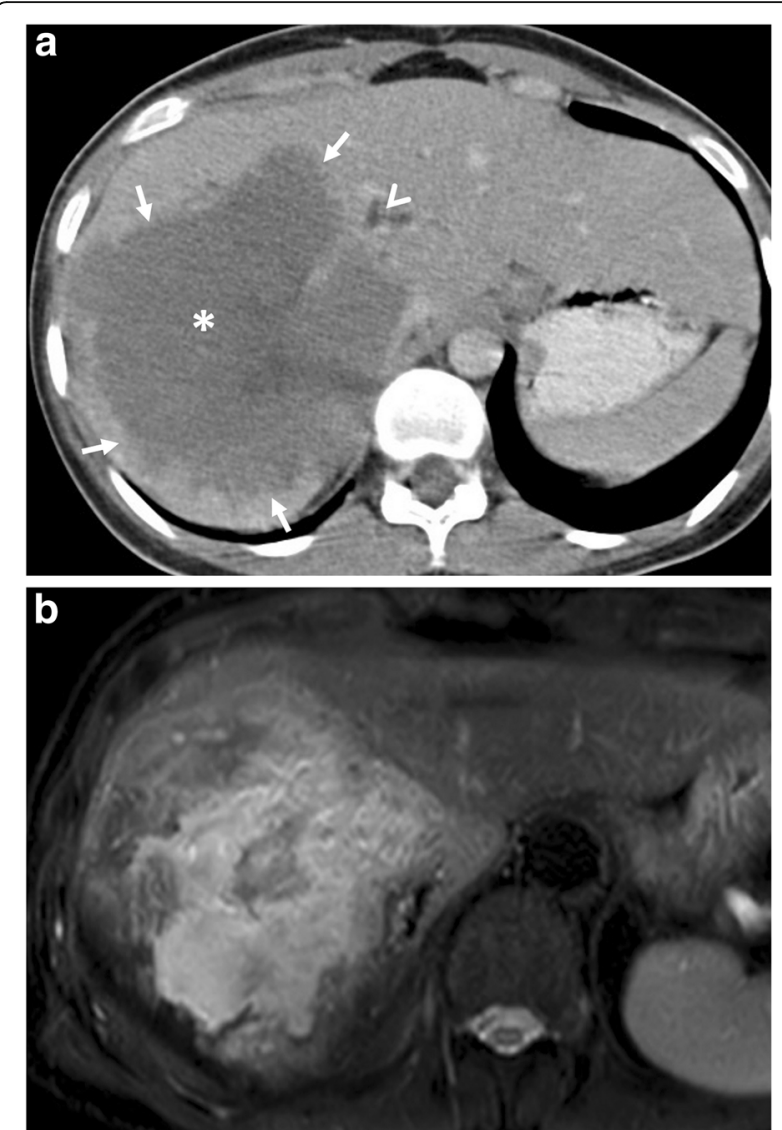

Fig. 6 A 21-year-old woman was admitted to the emergency department with a 2-week history of jaundice and upper right quadrant pain. a Axial contrast-enhanced $C T$ image demonstrates a heterogeneous infiltrative liver mass (asterisk) with irregular margins (arrows). The presence of biliary dilatation (arrowhead) due to compression of the mass was also noted. The diagnosis of alveolar echinococcosis was made by histopathological examination. b Fat saturated T2-weighted MR-image demonstrates internal heterogeneity of the mass mimicking primary liver malignancy. Chest CT findings were unremarkable for hydatid disease (not shown)

\section{Amoebiasis}

Amoebiasis is a parasitic disease caused by Entamoeba histolytica. Humans are the only natural hosts. Ingestion of the cyst from contaminated food or water initiates the infection. The cyst forms the trophozoite stage within the terminal ileum or colon [57]. The trophozoite form causes disease and may spread to the extraintestinal localizations via the portal vein, the lymphatics, or by direct extension through the peritoneum [58].

Most of the infected patients are asymptomatic; however, about $10 \%$ may show with clinical symptoms. The right-side colon tends to be more severely involved. The terminal ileum may be involved up to $10 \%$ [44]. Acute amebic colitis presents with bloody diarrhea, tenesmus,
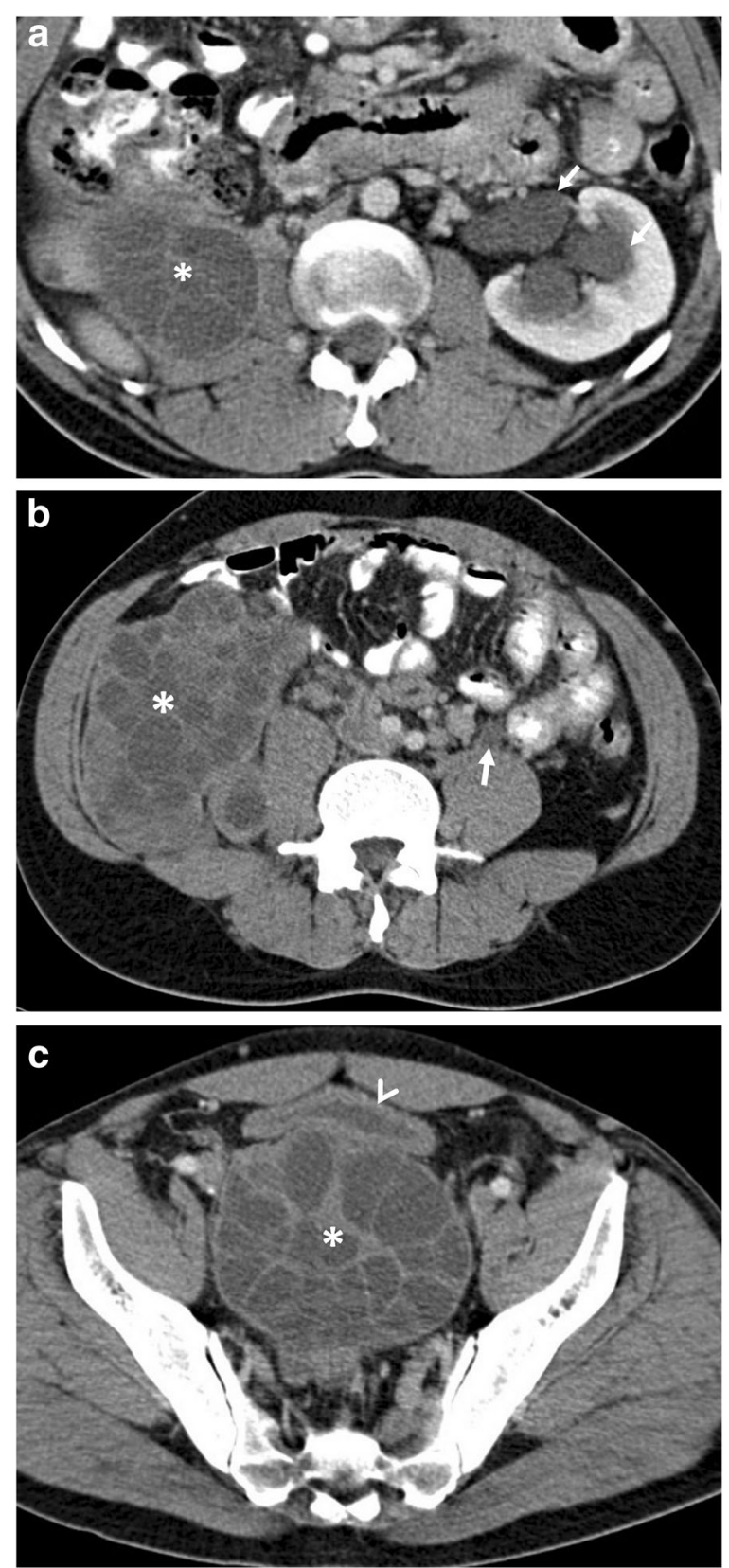

Fig. 7 A 25-year-old man presented to the emergency department with a 1-week history of fever, voiding difficulty, and bilateral flank pain. Blood analysis revealed leukocytosis and elevated serum creatinine levels. a-c Axial contrast-enhanced CT images show a large retroperitoneal Gharbi type 3 hydatid cyst extending from the right kidney to the pelvic region (asterisks, $\mathbf{a}-\mathbf{c}$ ). The right kidney is no longer visible on $\mathrm{CT}$ due to the replacement of renal parenchyma with a hydatid cyst. Left-sided hydroureteronephrosis (arrows, $\mathbf{a}$ and $\mathbf{b}$ ) was evident due to left ureteral compression by the pelvic portion of the hydatid cyst. Significantly compressed bladder (arrowhead, c) was also noted. Histopathological examination following surgery revealed the diagnosis of retroperitoneal hydatid disease and associated right kidney involvement 

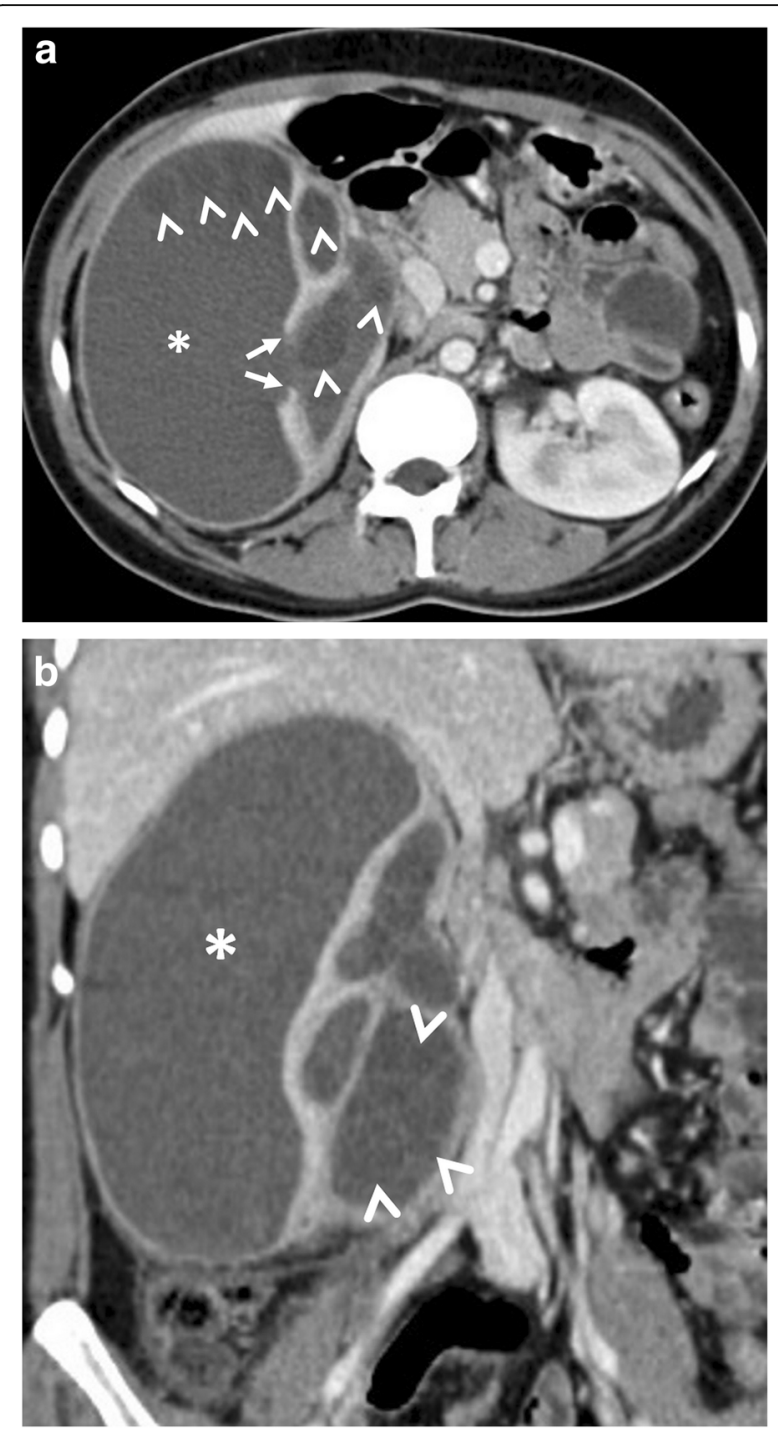

Fig. 8 A 24-year-old woman was admitted to the emergency department with an acute onset of right flank pain and fever. Increased serum levels of acute-phase reactants, leukocytosis, and elevated serum creatinine levels were evident at blood analysis. a, b Axial (a) and coronal (b) contrast-enhanced CT images demonstrate a large renal subcapsular Gharbi type 3 hydatid cyst (asterisks) rupture into the pelvicalyceal system. Loss of integrity of the renal parenchyma found on CT image indicates the site of rupture (arrows, a). Daughter cysts within the cyst and also in the pelvicalyceal system are noted (arrowheads, $\mathbf{a}, \mathbf{b}$ ). The diagnosis was confirmed by histopathological examination following surgery

and abdominal pain $[57,58]$. In amebic colitis, CT may demonstrate wall thickening, mucosal edema, and increased mucosal enhancement (Fig. 14) [44]. Fulminant amebic colitis is characterized by transmural extension of amebic colitis which may result in total colonic gangrene and bowel perforation [44,59]. Imaging features of fulminant amebic colitis include deep ulcerations,
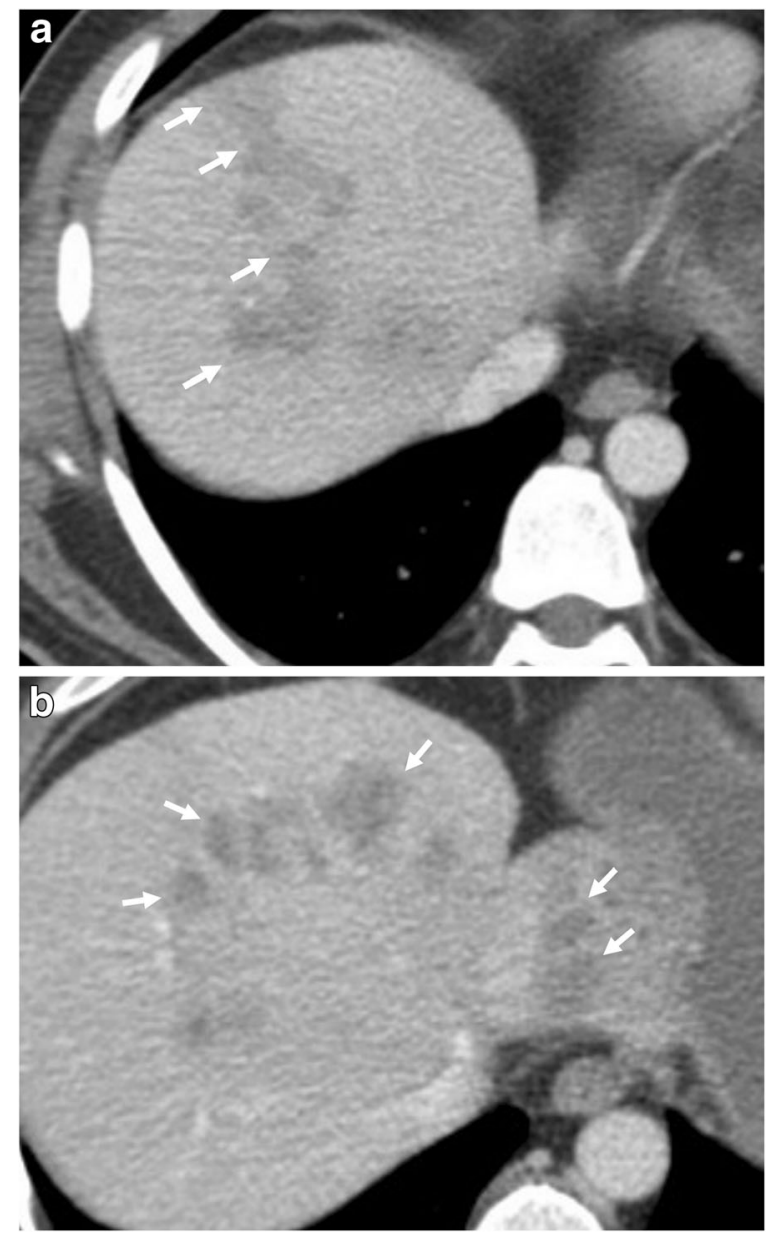

Fig. 9 A 49-year-old man was admitted to the emergency department with a 1-week history of fatigue, fever, and abdominal pain. Blood analysis was unremarkable except for the presence of eosinophilia. a, b Axial contrast-enhanced CT-images demonstrate patchy areas of decreased attenuation migrating from liver capsule through to deep parenchyma (arrows, a, b). Although not confirmed histopathologically, imaging-based diagnosis of $F$. hepatica infection was made depending on the distribution of parenchymal hypodensities on $C T$

submucosal and intramural tracking of contrast agent, and discontinuous bowel necrosis seen as alternating enhancing and nonenhancing bowel wall [84].

The most common extraintestinal manifestation of the disease is a liver abscess. Symptoms of liver abscess are fever, right upper quadrant pain, and tenderness [57]. Amebic abscesses are predominantly solitary, oval or round shaped, and located near the liver capsule in the right lobe of the liver. Sonographic features of amebic abscess consist of a hypoechoic lesion with low-level internal echoes and the absence of significant wall echoes. On CT scan, it is seen as a low-density lesion with a 

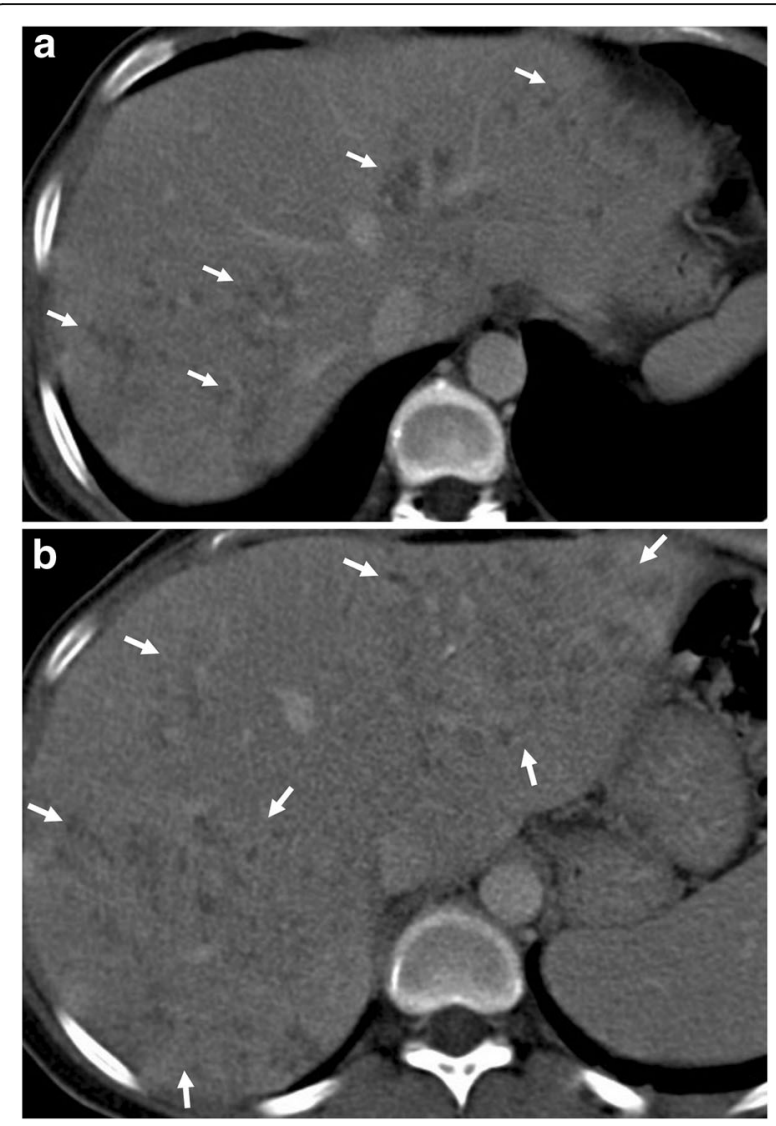

Fig. 10 A 33-year-old woman was admitted to the emergency department with a 4-day history of right upper quadrant pain, fever, and fatigue. Blood analysis revealed leukocytosis, increased serum level of CRP, eosinophilia, and increased level of liver enzymes. $\mathbf{a}, \mathbf{b}$ Axial contrast-enhanced CT-images show nodular irregular areas of decreased attenuation scattered through the liver parenchyma (arrows). The distribution of lesions was compatible with the clusters of microabscesses seen in $F$. hepatica infection. Indirect hemagglutination test positivity for F. hepatica and imaging findings supported the diagnosis

peripheral enhancing rim thickened wall. A mild contrast enhancement around the abscess in the adjacent liver parenchyma occurs due to the peripheral zone of edema [85]. Amebic liver abscess is frequently together with right-sided pleural effusion and perihepatic fluid [44].

\section{Malaria}

Malaria is a serious parasitic infectious disease that is caused by Plasmodium species. Plasmodium species are transmitted through infected female mosquitoes that bite humans. These parasites grow within erythrocytes and are released by cyclic hemolysis [60].

The main symptom of malaria is episodic fever [60]. One of the most commonly involved systems during acute malaria is the gastrointestinal tract. Gastrointestinal symptoms are common in children with falciparum malaria. Abdominal symptoms of malaria are vomiting, dyspepsia, diarrhea, abdominal pain, and intestinal hemorrhage [61]. Acute pancreatitis, acalculous cholecystitis, and subacute intestinal obstruction are rare complications of the falciparum malaria. The precise mechanism of these complications is not clearly defined. Plasmodium falciparum infection was stipulated to have resulted in microvascular obstruction and consequently result in affected organ ischemia [14]. Rarely perforation can also occur [62]. Splenomegaly is the most common finding on $\mathrm{CT}$ examination in patients with gastrointestinal symptoms (Fig. 15). Other findings are hepatomegaly, splenic infarction, spontaneous splenic rupture and hemorrhage, ascites, and periportal edema [60, 63]. In patients with malaria and acute abdominal pain, CT is the mainstay imaging technique in the differentiation between splenic infarction and spontaneous rupture. Discontinuation of splenic contours, heterogeneous enhancement of splenic parenchyma, and perisplenic and intraabdominal free fluid with density levels ranging between 35 and $60 \mathrm{HU}$ that suggests hemoperitoneum and presence of highest attenuation of the intraabdominal free fluid (sentinel clot) nearest to spleen should suggest splenic rupture in patients with suspicion of malaria due to travel history to the endemic areas [64]. Patients with malaria have also been reported to develop non-cardiogenic pulmonary edema and acute respiratory distress syndrome (ARDS) due to increased capillary permeability or endothelial damage (Fig. 15) $[65,66]$.

\section{Visceral leishmaniasis}

Leishmaniasis is a vector-borne parasitic disease caused by Leishmania species. There are 3 main forms of leishmaniases: cutaneous, mucocutaneous, and visceral [68]. Persistent irregular fever and splenomegaly are characteristic findings for visceral leishmaniasis. Besides, lymphadenopathy, hepatomegaly, pallor, night sweats, weakness, anorexia, asthenia, cutaneous pigmentation, and weight loss may be seen. Left upper quadrant pain may be caused by massive splenomegaly [68]. Gastrointestinal hemorrhage may be encountered in leishmaniasis due to the involvement of bowels as the duodenum being the most frequently involved segment [69].

Regarding US findings in the patients, splenomegaly, lymphadenopathy, and hepatomegaly are common. Less common sonographic findings include ascites, pleural effusion, portal vein dilatation, and inferior vena cava dilatation. Increased echogenicity of the kidneys and decreased echogenicity of the pancreas may be seen very rarely [70]. On contrast-enhanced $\mathrm{CT}$, hepatosplenomegaly, hypodense nodular lesions 

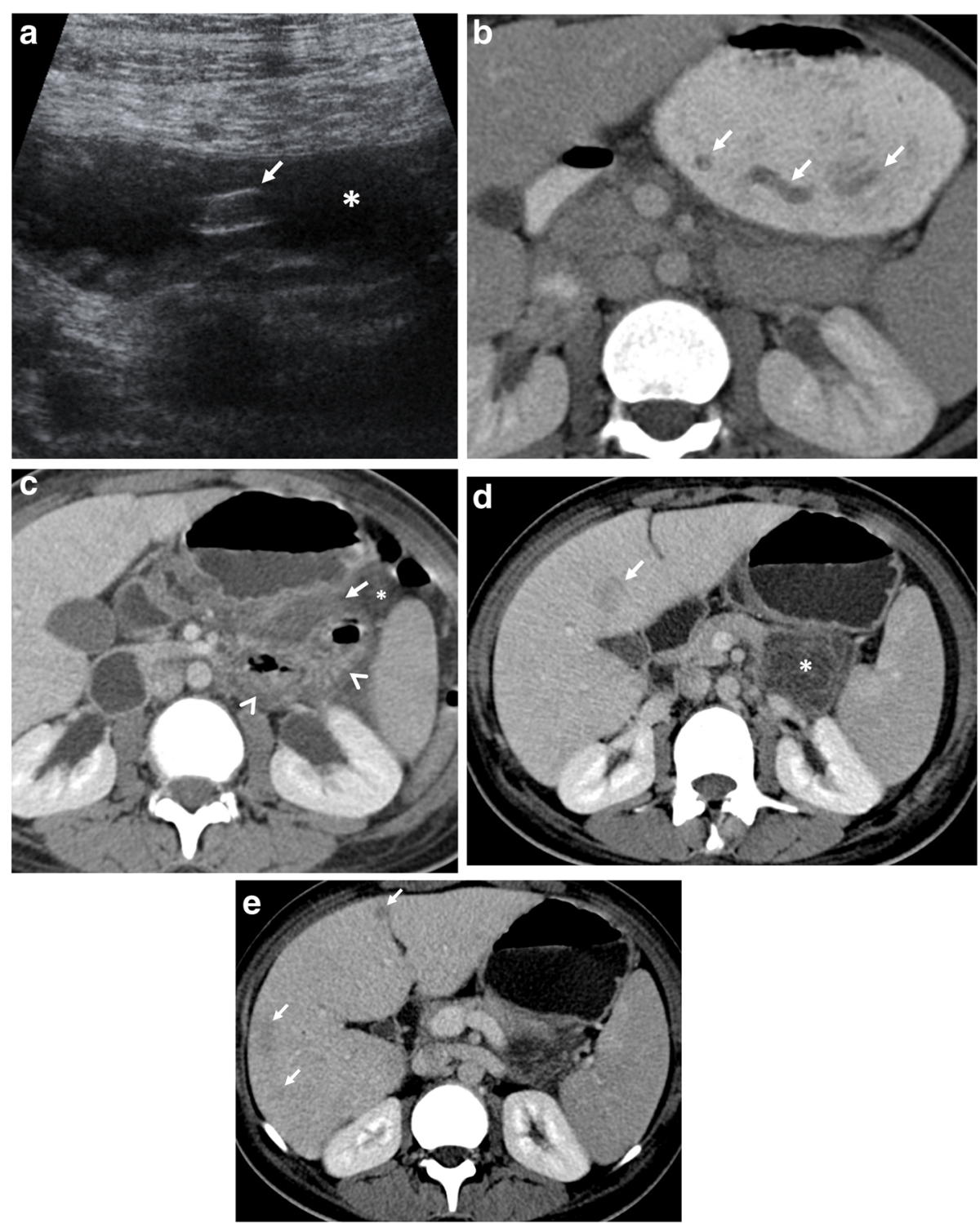

Fig. 11 A 21-year-old woman was admitted to the emergency department with a 1-week history of vomiting and abdominal pain. Physical examination was unremarkable except for mild epigastric tenderness. Increased serum levels of acute-phase reactants and eosinophilia were evident at blood analysis. a Axial gray-scale US image demonstrates a tubular structure (arrow) within the lumen of the stomach (asterisk). b Axial contrast-enhanced CT scan more clearly depicts the worm (arrows). c Follow-up CT scan was obtained on the 3rd day of admission due to clinical suspicion of acute pancreatitis. Mild fat stranding (arrow) and fluid (asterisk) with jejunal wall thickening (arrowheads) were noted on CT. d, e Follow-up CT scans obtained on the 5th day of admission demonstrate the evolution of peripancreatic inflammatory changes into a heterogeneous fluid collection (asterisk, d). Peripherally located liver lesions (arrows, d, e) were also noted. Imaging findings raised suspicion for the involvement of visceral larva migrans. The definitive diagnosis was achieved with the identification of Ascaris eggs in the stool examination

in the liver, and spleen and lymphadenopathy may be detected (Fig. 16). CT angiography may reveal intraluminal contrast extravasation in cases with gastrointestinal hemorrhage. In the differential diagnosis, lymphoma should be kept in mind due to the abovementioned mimicking findings [71, 72]. Rarely, splenic infarction and splenic rupture may occur.

\section{Anisakiasis}

Ingestion of raw or undercooked fish or other seafood may cause a rare parasitic disease, Anisakiasis [75]. There is a controversy in previous reports about the ability of the larvae of genus Anisakis during penetration of the gastrointestinal wall. Some reports indicate that the larva can only be stuck on the gastrointestinal wall 

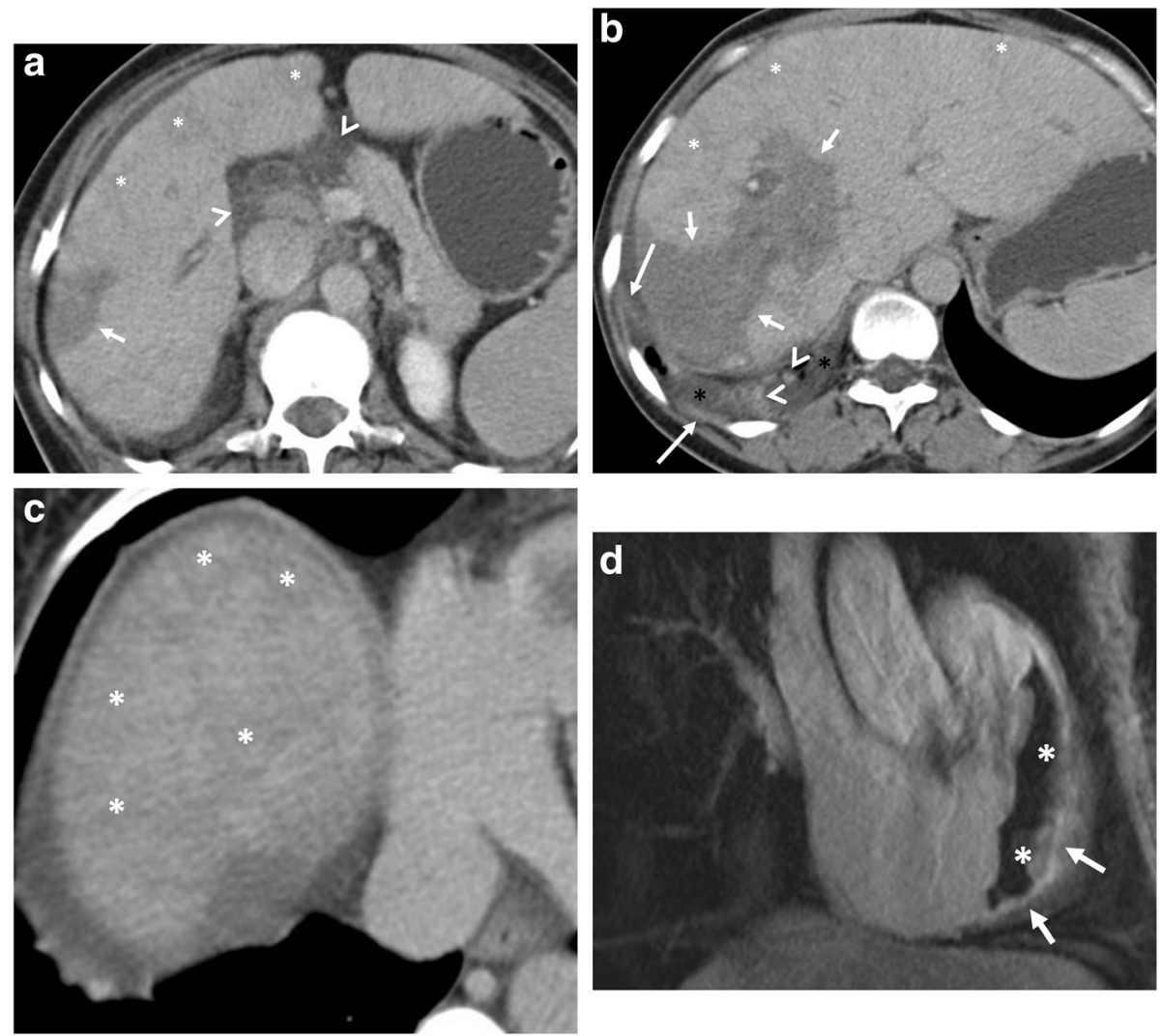

Fig. 12 A 49-year-old woman was admitted to the emergency department with a 1-week history of fever, shortness of breath, and weight loss. Physical examination revealed tachycardia. Increased serum level of acute phase reactants, eosinophilia, and increased level of liver enzymes were evident at blood analysis. a-c Axial contrast-enhanced CT images demonstrate periportal fat tissue stranding (arrowheads, a) and parenchymal hypodensity affecting right liver lobe (arrows, $\mathbf{a}, \mathbf{b}$ ). Areas of decreased parenchymal attenuation scattered at the periphery of the liver were also noted on CT (asterisks, a-c). The presence of complex pleural effusion (black asterisks) containing nodular (arrowheads, b) and linear (long arrows, b) areas of contrast enhancement, was consistent with pleural involvement. Liver biopsy revealed liver injury and the presence of eosinophilic infiltration. CT image at the level of liver dome demonstrates the parenchymal involvement (asterisks, c). d Sagittal reformatted T1-weighted inversion-recovery MR image obtained 10 min following IV gadolinium-based contrast agent injection, shows biventricular apical thrombus (asterisks) and subendocardial contrast enhancement (arrows) suggestive of Loeffler's endocarditis. The definitive diagnosis of the Toxocara infection was made by serological tests

while others emphasize the penetrating ability of the parasite [75-77]. Attachment of larvae in the gastrointestinal wall causes local tissue damage including ulceration, granulomatous inflammation, or perforation while an allergic reaction of the gastrointestinal wall or IgE-mediated systemic allergic reaction may also occur [76]. Gastric involvement forms $90-95 \%$ of cases [77]. Symptoms include abrupt onset of abdominal pain, nausea, vomiting, fever in gastric anisakiasis with additional diarrhea, peritoneal irritation, and intestinal obstruction caused by intussusception in intestinal anisakiasis $[75,77]$. Diagnosis of anisakiasis with imaging findings solely is usually difficult if one neglects the history of raw or undercooked seafood consumption. US, as a frequently used imaging technique in epigastric or right upper quadrant pain, may demonstrate diffuse concentric wall thickening in gastric or intestinal walls with hypoechoic submucosal edema, irregularity of the lumen surface due to edema of the Kerckring's folds (corn sign), and accompanying free fluid around involved segment [75].

The features of anisakiasis in $\mathrm{CT}$ imaging during gastric and intestinal involvement include gastric or intestinal wall thickening due to submucosal edema, perigastric fat stranding in gastric anisakiasis, and trace ascites. Prompt diagnosis of gastric anisakiasis can be accomplished with endoscopy followed by endoscopic removal of larvae. Management of intestinal anisakiasis depends on conservative medical treatment with antihelminthic drugs such as albendazole [77]. 

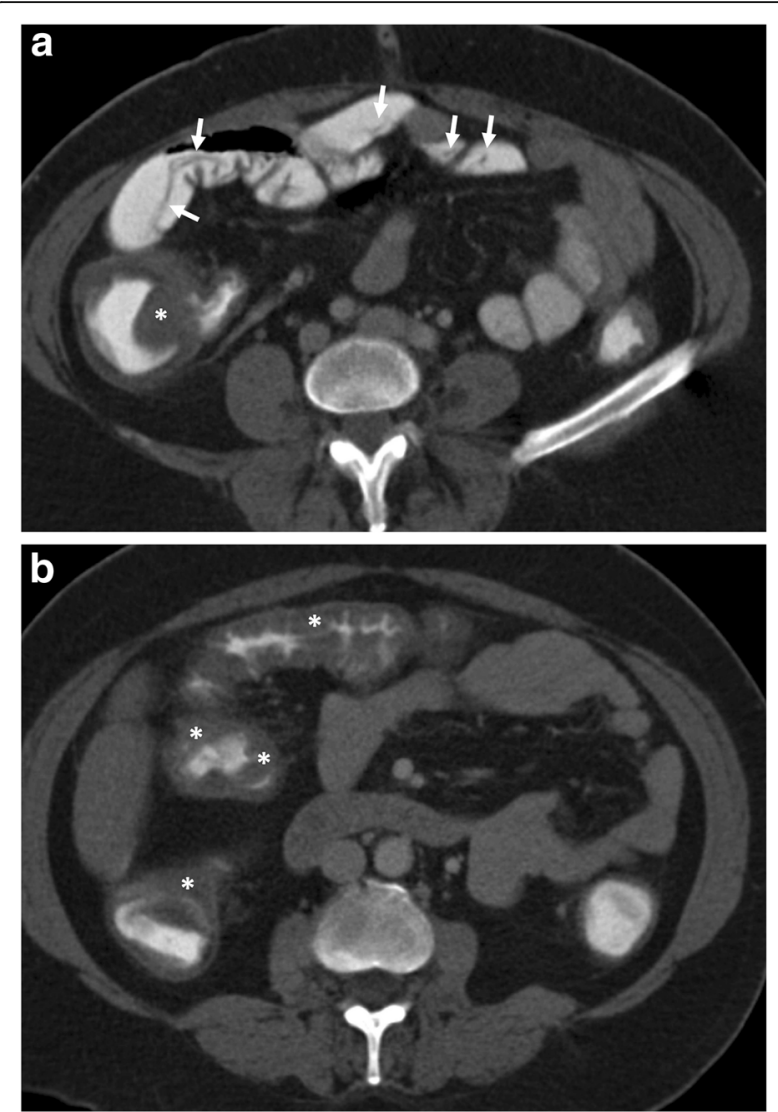

Fig. 13 A 45-year-old woman was admitted to the emergency department with a 2-week history of diarrhea and abdominal pain. a, b Axial contrast-enhanced CT images demonstrate multiple tubular filling defects in the small bowel (arrows). Colonic wall thickening, indicating colitis, is also noted (asterisks, $\mathbf{a}, \mathbf{b}$ ). The definitive diagnosis of intestinal taeniasis was achieved following the stool examination

\section{Dientamoebiasis}

Dientamoeba fragilis is a protozoan parasite of the human bowel. It has been considered for years to be a nonpathogenic organism but more recent reports throughout the world show association of this parasite with gastrointestinal symptoms [86]. The most common symptoms of dientamoebiasis are diarrhea, abdominal pain, loose stools, and anorexia [87]. Acute abdominal pain is a rare symptom [73, 88]. CT may demonstrate nonspecific inflammatory changes due to involvement (Fig. 17).

\section{Conclusion}

Acute abdominal pain may be seen in parasitic diseases. The diagnosis can be delayed because of the similar clinical signs encountered in other frequently
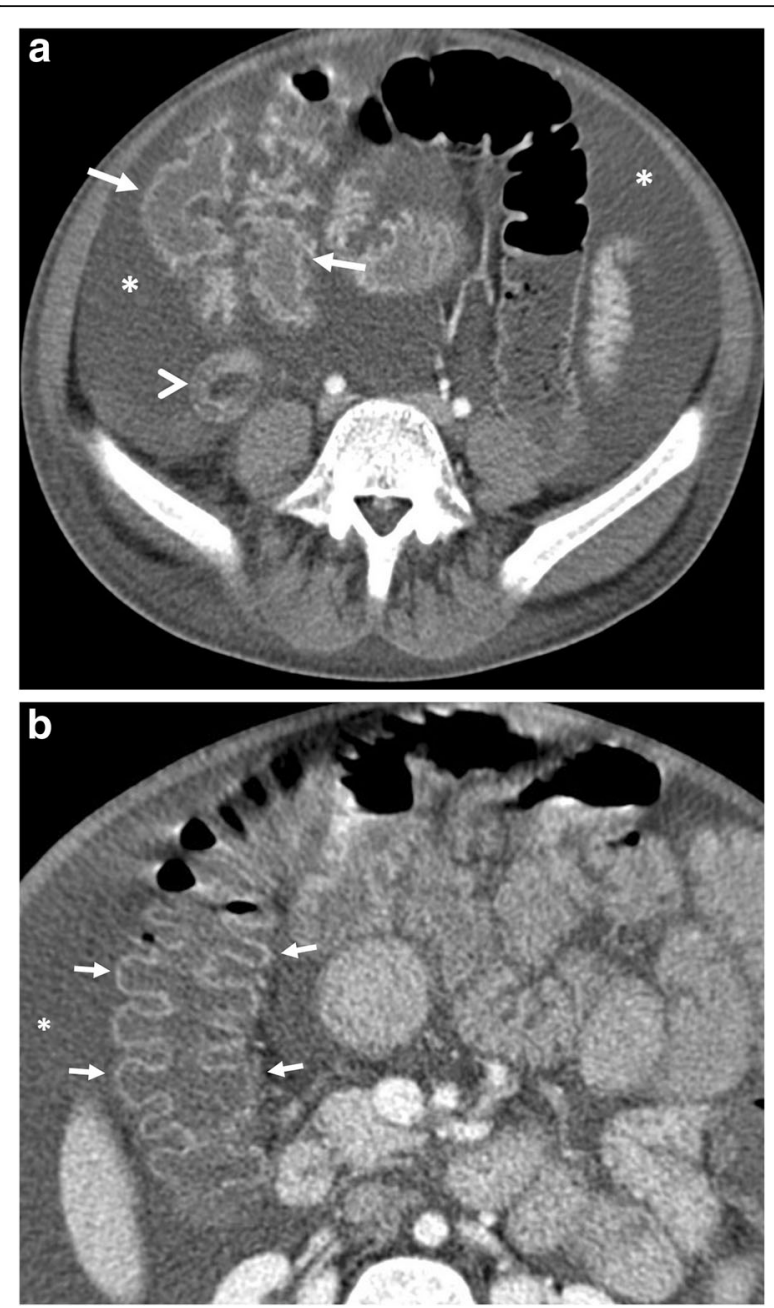

Fig. 14 A 12-year-old boy was admitted to the emergency department with a 3-day history of hematochezia and diarrhea. He also complained of abdominal pain and abdominal distention. Physical examination revealed diffuse abdominal tenderness. Increased serum levels of acute-phase reactants and leukocytosis were evident at blood analysis. a, b Axial contrast-enhanced CT images demonstrate wall thickening and contrast enhancement of the appendix vermiformis (arrowhead) and ileum (arrows, a). Intraabdominal free fluid (asterisks, a, b) and increased mucosal enhancement of the colon (arrows, b) are also noted. Mucosal ulcers were evident at colonoscopy. Histopathological examination revealed the presence of trophozoits of Entamoeba histolytica, superficial ulcers, and lymphangiectasia at the lamina propria of the small bowel

seen causes of acute abdomen. Therefore, parasitic infections should be included in the differential diagnosis of acute abdominal pain particularly in patients from known endemic areas. Awareness of imaging findings in abdominal parasitic involvement is triggering to raise the suspicion for parasitic disease as a cause of acute abdominal pain. 

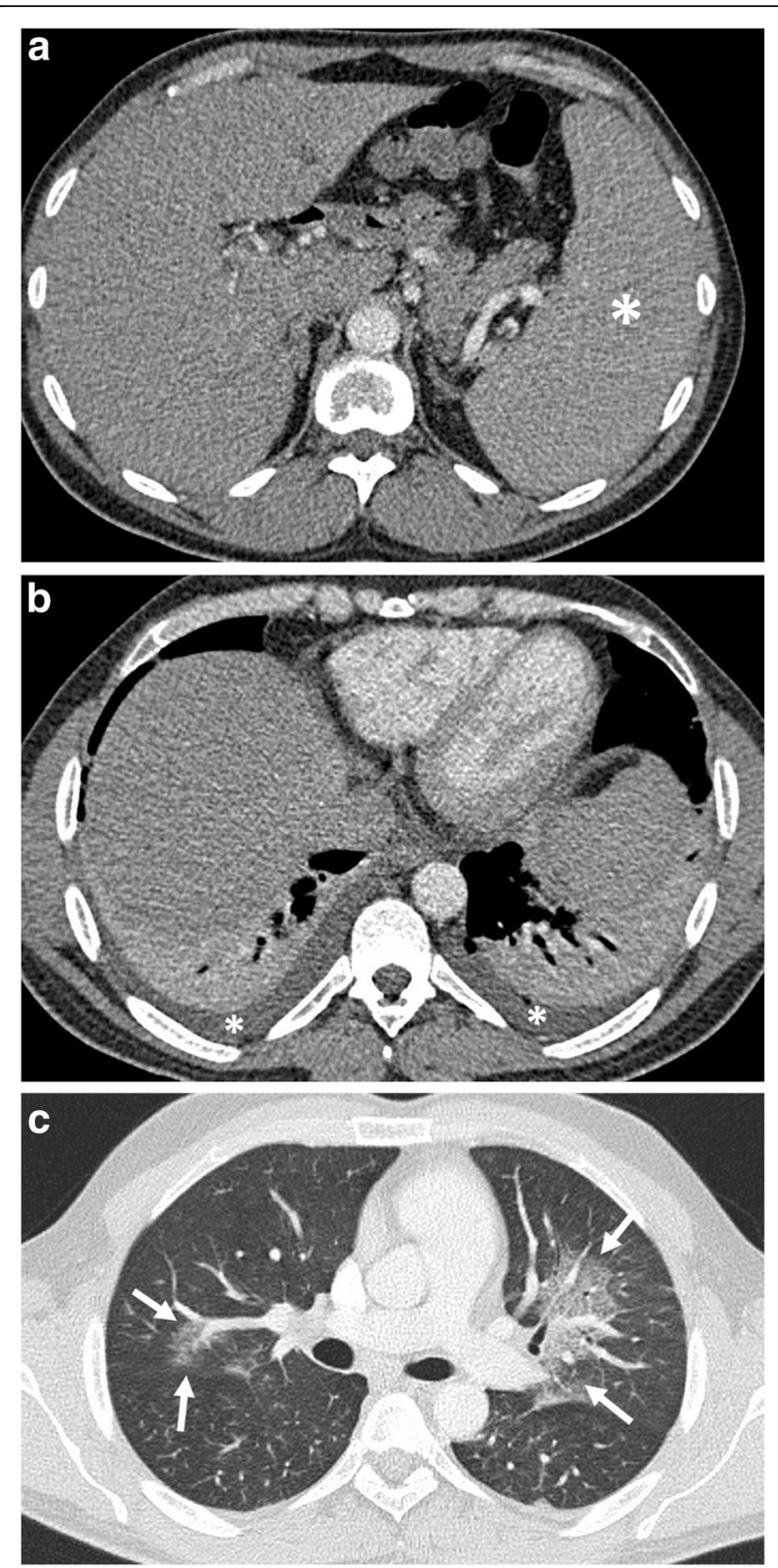

Fig. 15 A 39-year-old man was admitted to the emergency department with a 1-week history of mild abdominal pain and fever. Physical examination was unremarkable except for splenomegaly. Blood analysis demonstrated thrombocytopenia. a Axial contrastenhanced CT image shows splenomegaly (asterisk). There was no sign of splenic infarction, hematoma, and rupture at the time of diagnosis. b, c CT scan of the chest showed bilateral mild pleural effusion (asterisks, $\mathbf{b}$ ) and centrally located ground-glass opacities (arrows, c). The findings raised suspicion for non-cardiogenic pulmonary edema. The imaging findings were not specific for any particular type of disorder. Nevertheless, the final diagnosis was made by a peripheral blood smear examination showing the plasmodium falciparum infection
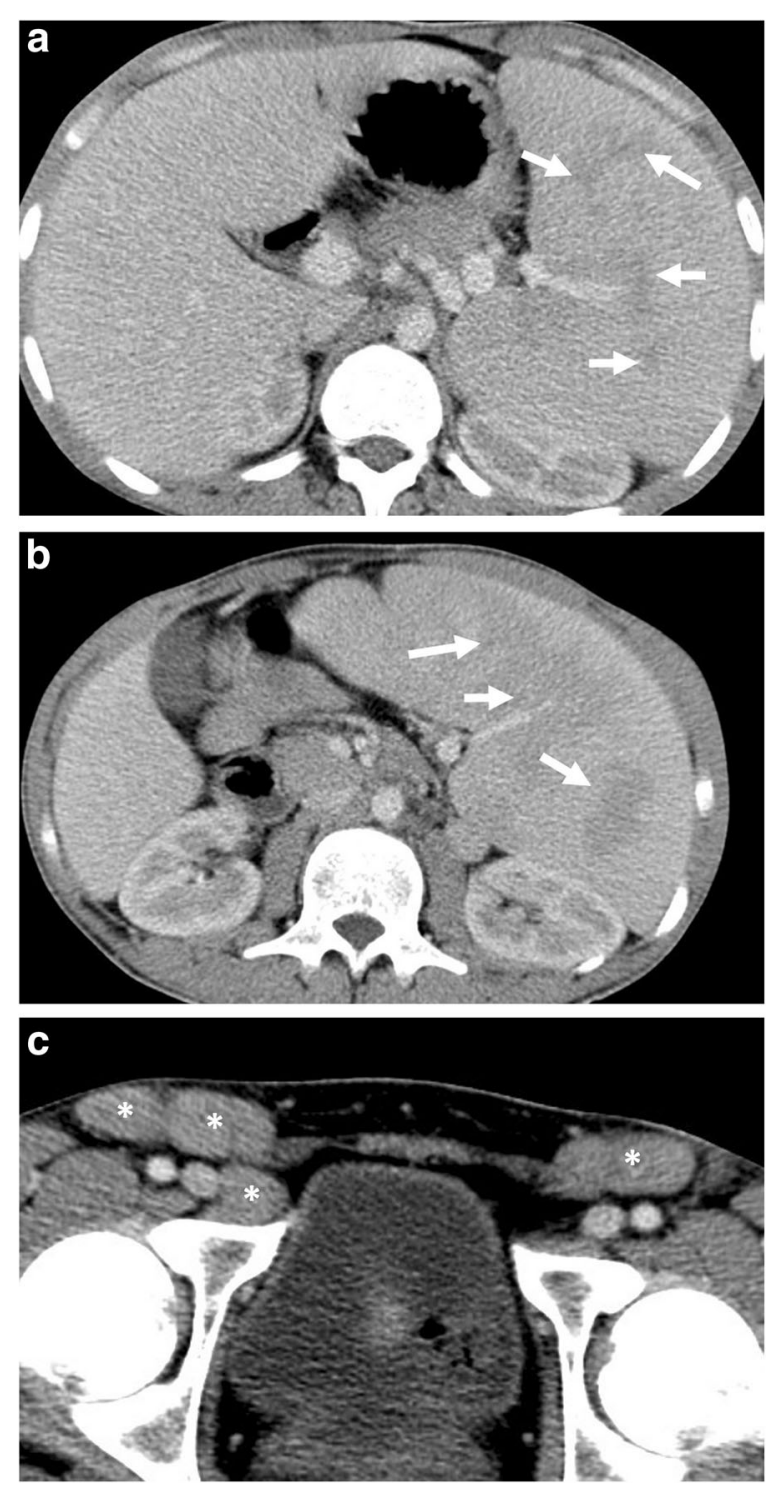

Fig. 16 A 21-old man was admitted to the emergency department with a 2-week history of left upper quadrant abdominal pain and fever. Physical examination revealed splenomegaly and inguinal lymphadenopathy. Increased serum levels of acute-phase reactants, leukocytosis, and high sedimentation were evident at blood analysis. a, c Axial contrast-enhanced portal venous phase $C T$ images demonstrate patchy areas of hypoattenuation (arrows, $\mathbf{a}, \mathbf{b}$ ) within the enlarged spleen and bilateral inguinal lymphadenopathy (asterisks, c). The liver was normal except for mild hepatomegaly (18 $\mathrm{cm}$ ). The diagnosis of Leishmaniasis was made by histopathological examination following splenectomy 

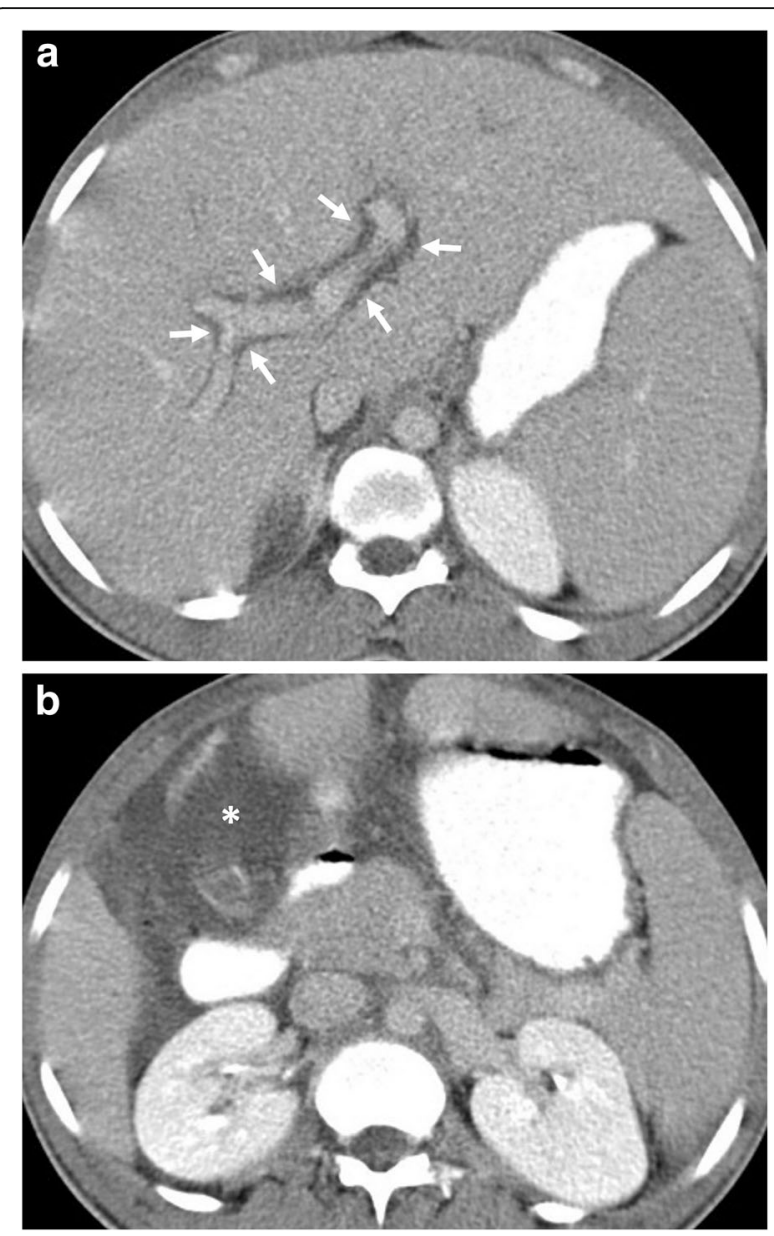

Fig. 17 A 23-year-old man was admitted to the emergency department with a 1-week history of abdominal pain and diarrhea. Physical examination and blood analysis were unremarkable except for mild abdominal tenderness and eosinophilia, respectively. a, b Axial contrast-enhanced $C T$ images demonstrate the presence of intra-abdominal free fluid (asterisk) and periportal edema (arrows). The imaging findings did not raise suspicion for an individual pathology. There was no definitive proof that this organism was the cause of the symptoms or imaging manifestation. Nevertheless, the patient's symptoms and imaging findings were completely resolved following the treatment for Dientamoeba fragilis which was found on the patient's stool examination

\section{Abbreviations}

CT: Computed tomography; MRI: Magnetic resonance imaging; US: Ultrasonography

\section{Authors' contributions}

All authors contributed equally in writing and editing the manuscript. All authors read and approved the final manuscript.

\section{Funding}

None

\section{Availability of data and materials}

Data sharing is not applicable to this article as no datasets were generated or analysed during the current study.
Ethics approval and consent to participate

Not applicable.

\section{Consent for publication}

Not applicable.

\section{Competing interests}

The authors declare that they have no competing interests.

Received: 19 February 2020 Accepted: 29 June 2020

Published online: 20 July 2020

\section{References}

1. Torgerson PR, Devleesschauwer B, Praet N et al (2015) World Health Organization estimates of the global and regional disease burden of 11 foodborne parasitic diseases, 2010: A Data Synthesis. PLoS Med 12:e1001920

2. Ortega CD, Ogawa NY, Rocha MS et al (2010) Helminthic diseases in the abdomen: an epidemiologic and radiologic overview. Radiographics 30: 253-267

3. Catalano OA, Sahani DV, Forcione DG et al (2009) Biliary infections: spectrum of imaging findings and management. Radiographics 29:2059-2080

4. Tappe D, Stich A, Frosch M (2008) Emergence of polycystic neotropical echinococcosis. Emerg Infect Dis 14:292-297

5. Grosso G, Gruttadauria S, Biondi A, Marventano S, Mistretta A (2012) Worldwide epidemiology of liver hydatidosis including the Mediterranean area. World J Gastroenterol 18:1425-1437

6. Baumann S, Shi R, Liu W et al (2019) Worldwide literature on epidemiology of human alveolar echinococcosis: a systematic review of research published in the twenty-first century. Infection 47:703-727

7. Mas-Coma MS, Esteban JG, Bargues MD (1999) Epidemiology of human fascioliasis: a review and proposed new classification. Bull World Health Organ 77:340-346

8. Pullan RL, Brooker SJ (2012) The global limits and population at risk of soiltransmitted helminth infections in 2010. Parasit Vectors 5:81

9. Macpherson CN (2013) The epidemiology and public health importance of toxocariasis: a zoonosis of global importance. Int J Parasitol 43:999-1008

10. Ale A, Victor B, Praet N et al (2014) Epidemiology and genetic diversity of Taenia asiatica: a systematic review. Parasit Vectors 7:45

11. Trevisan C, Sotiraki S, Laranjo-Gonzalez M et al (2018) Epidemiology of taeniosis/cysticercosis in Europe, a systematic review: eastern Europe. Parasit Vectors 11:569

12. Rajshekhar V, Joshi DD, Doanh NQ, van De N, Xiaonong Z (2003) Taenia solium taeniosis/cysticercosis in Asia: epidemiology, impact and issues. Acta Trop 87:53-60

13. Shirley DT, Farr L, Watanabe K, Moonah S (2018) A review of the global burden, new diagnostics, and current therapeutics for amebiasis. Open Forum Infect Dis; 5:ofy161

14. Zaki SA, Shanbag P (2011) Atypical manifestations of malaria. Res Rep Trop Med 2:9-22

15. Autino B, Noris A, Russo R, Castelli F (2012) Epidemiology of malaria in endemic areas. Mediterr J Hematol Infect Dis 4:e2012060

16. Georgiadou SP, Makaritsis KP, Dalekos GN (2015) Leishmaniasis revisited: Current aspects on epidemiology, diagnosis and treatment. J Transl Int Med 3:43-50

17. Stark D, Barratt J, Roberts T, Marriott D, Harkness J, Ellis J (2010) A review of the clinical presentation of dientamoebiasis. Am J Trop Med Hyg 82:614619

18. Carnero PR, Mateo PH, Martín-Garre S, Pérez ÁG, Del Campo LJ (2017) Unexpected hosts: imaging parasitic diseases. Insights Imaging 8:101-125

19. Parashari UC, Upadhyay D, Khanduri S, Qayyum FA, Bhadury S (2011) Primary renal hydatidosis with associated macroscopic hydatiduria--a computed tomography urography diagnosis with pathological confirmation. Trop Doct 41:187-189

20. Polat P, Kantarci M, Alper F, Suma S, Koruyucu MB, Okur A (2003) Hydatid disease from head to toe. Radiographics 23:475-494 quiz 536-477

21. Pedrosa I, Saiz A, Arrazola J, Ferreiros J, Pedrosa CS (2000) Hydatid disease: radiologic and pathologic features and complications. Radiographics 20 : 795-817

22. Gharbi HA, Hassine W, Brauner MW, Dupuch K (1981) Ultrasound examination of the hydatic liver. Radiology 139:459-463 
23. WHO Informal Working Group (2003) International classification of ultrasound images in cystic echinococcosis for application in clinical and field epidemiological settings. Acta Trop 85:253-261

24. Akhan O, Ozmen MN, Dincer A, Sayek I, Gocmen A (1996) Liver hydatid disease: long-term results of percutaneous treatment. Radiology 198: 259-264

25. Akhan O, Salik AE, Ciftci T, Akinci D, Islim F, Akpinar B (2017) Comparison of long-term results of percutaneous treatment techniques for hepatic cystic echinococcosis types 2 and 3b. AJR Am J Roentgenol 208:878-884

26. Marrone G, Crino F, Caruso S et al (2012) Multidisciplinary imaging of liver hydatidosis. World J Gastroenterol 18:1438-1447

27. Antonopoulos P, Tavernaraki K, Charalampopoulos G, Constantinidis F, Petroulakis A, Drossos C (2008) Hydatid hepatic cysts rupture into the biliary tract, the peritoneal cavity, the thoracic cavity and the hepatic subcapsular space: specific computed tomography findings. Abdom Imaging 33:294-300

28. Alghofaily KA, Saeedan MB, Aljohani IM et al (2017) Hepatic hydatid disease complications: review of imaging findings and clinical implications. Abdom Radiol (NY) 42:199-210

29. Derici H, Tansug T, Reyhan E, Bozdag AD, Nazli O (2006) Acute intraperitoneal rupture of hydatid cysts. World J Surg 30:1879-1883 discussion 1884-1875

30. Czermak BV, Unsinn KM, Gotwald T et al (2001) Echinococcus multilocularis revisited. AJR Am J Roentgenol 176:1207-1212

31. Kusaslan R, Sahin DA, Belli AK, Dilek ON (2007) Rupture of a mesenteric hydatid cyst: a rare cause of acute abdomen. Can J Surg 50:E3-E4

32. Mandell G, Dolin R, Bennett J (2019) Mandell, Douglas, and Bennett's principles and practice of infectious diseases, 9th edn. Elsevier, chapter 288 : 3459-3460

33. Mas-Coma S, Bargues MD, Valero MA (2005) Fascioliasis and other plantborne trematode zoonoses. Int J Parasitol 35:1255-1278

34. Lim JH, Mairiang E, Ahn GH (2008) Biliary parasitic diseases including clonorchiasis, opisthorchiasis and fascioliasis. Abdom Imaging 33:157-165

35. Dusak A, Onur MR, Cicek M, Firat U, Ren T, Dogra VS (2012) Radiological imaging features of Fasciola hepatica infection-a pictorial review. J Clin Imaging Sci; 2:2

36. Koc Z, Ulusan S, Tokmak N (2009) Hepatobiliary fascioliasis: imaging characteristics with a new finding. Diagn Interv Radiol 15:247-251

37. Lim JH, Kim SY, Park CM (2007) Parasitic diseases of the biliary tract. AJR Am J Roentgenol 188:1596-1603

38. Kabaalioglu A, Ceken K, Alimoglu E et al (2007) Hepatobiliary fascioliasis: sonographic and CT findings in 87 patients during the initial phase and long-term follow-up. AJR Am J Roentgenol 189:824-828

39. Han JK, Jang HJ, Choi Bl et al (1999) Experimental hepatobiliary fascioliasis in rabbits: a radiology-pathology correlation. Invest Radiol 34:99-108

40. Fica A, Dabanch J, Farias C, Castro M, Jercic MI, Weitzel T (2012) Acute fascioliasis_clinical and epidemiological features of four patients in Chile. Clin Microbiol Infect 18:91-96

41. Riedtmann HJ, Obeid T, Aeberhard P, Sakmann P (1995) Fasciola hepatica-a unusual cause of acute cholecystitis with cholestatic jaundice. Schweiz Med Wochenschr 125:1642-1648

42. Sezgin O, Altintas E, Tombak A, Ucbilek E (2010) Fasciola hepatica-induced acute pancreatitis: report of two cases and review of the literature. Turk J Gastroenterol 21:183-187

43. Echenique-Elizondo M, Amondarain J, Liron de Robles C (2005) Fascioliasis: an exceptional cause of acute pancreatitis. JOP 6:36-39

44. Park MS, Kim KW, Ha HK, Lee DH (2008) Intestinal parasitic infection. Abdom Imaging 33:166-171

45. Khuroo MS, Zargar SA, Mahajan R (1990) Hepatobiliary and pancreatic ascariasis in India. Lancet 335:1503-1506

46. Kenamond CA, Warshauer DM, Grimm IS (2006) Best cases from the AFIP: Ascaris pancreatitis. Radiographics 26:1567-1570

47. Darlington Cd Mbbs MS, Anitha Gfs Mbbs MD (2018) Ascaridial volvulus: an uncommon cause of ileal perforation. Iran J Med Sci 43:432-435

48. Das CJ, Kumar J, Debnath J, Chaudhry A (2007) Imaging of ascariasis. Australas Radiol 51:500-506

49. Lynser D, Handique A, Daniala C, Phukan P, Marbaniang E (2015) Sonographic images of hepato-pancreatico-biliary and intestinal ascariasis: A pictorial review. Insights Imaging 6:641-646

50. Zammarchi L, Strohmeyer M, Bartalesi F et al (2013) Epidemiology and management of cysticercosis and Taenia solium taeniasis in Europe, systematic review 1990-2011. PLoS One 8:e69537
51. Bekraki A, Hanna K (2016) Peritonitis caused by jejunal perforation with Taenia saginata: report of a case. J Parasit Dis 40:203-204

52. Hakeem SY, Rashid A, Khuroo S, Bali RS (2012) Taenia saginata: a rare cause of gall bladder perforation. Case Rep Surg 2012:572484

53. Liu YM, Bair MJ, Chang WH, Lin SC, Chan YJ (2005) Acute pancreatitis caused by tapeworm in the biliary tract. Am J Trop Med Hyg 73:377-380

54. Chakrabarti I, Gangopadhyay M, Bandopadhyay A, Das NK (2014) A rare case of gangrenous appendicitis by eggs of Taenia species. J Parasit Dis 38:135-137

55. Yu HJ, Ahn CS, Lim S et al (2019) Biliary taeniasis with cholecystitis: an unusual case of Taenia solium infection with a literature review. Am J Trop Med Hyg 100:135-139

56. Fabijanic D, Giunio L, Ivani N, Fabijanic A, Miric D, Kardum D (2001) Ultrasonographic appearance of colon taeniasis. J Ultrasound Med 20:275-277

57. Stanley SL (2003) Amoebiasis. Lancet 361:1025-1034

58. Salles JM, Salles MJ, Moraes LA, Silva MC (2007) Invasive amebiasis: an update on diagnosis and management. Expert Rev Anti Infect Ther 5:893-901

59. Chaturvedi R, Gupte PA, Joshi AS (2015) Fulminant amoebic colitis: a clinicopathological study of 30 cases. Postgrad Med J 91:200-205

60. Kim EM, Cho HJ, Cho CR, Kwak YG, Kim MY, Cho YK (2010) Abdominal computed tomography findings of malaria infection with Plasmodium vivax. Am J Trop Med Hyg 83:1202-1205

61. Sowunmi A, Ogundahunsi OA, Falade CO, Gbotosho GO, Oduola AM (2000) Gastrointestinal manifestations of acute falciparum malaria in children. Acta Trop 74:73-76

62. Bhandari TR, Shahi S, Poudel R, Chaudhary N (2016) A child with severe malaria presenting with acute surgical abdomen (Duodenal Perforation) Case Rep Pediatr 2016:3092130

63. Hwang JH, Lee CS (2014) Malaria-induced splenic infarction. Am J Trop Med Hyg 91:1094-1100

64. Tonolini M, lerardi AM, Carrafiello G (2016) Atraumatic splenic rupture, an underrated cause of acute abdomen. Insights Imaging 7:641-646

65. Elzein F, Mohammed N, Ali N, Bahloul A, Albadani A, Alsherbeeni N (2017) Pulmonary manifestation of Plasmodium falciparum malaria: case reports and review of the literature. Respir Med Case Rep 22:83-86

66. Taylor WRJ, Hanson J, Turner GDH, White NJ, Dondorp AM (2012) Respiratory manifestations of malaria. Chest 142:492-505

67. Rovira RE, Diaz-Gomez JR, Lapuebla X, Aguar MC (2005) [Spontaneous rupture of the spleen in a patient with visceral leishmaniasis]. Enferm Infecc Microbiol Clin; 23:327

68. Torres-Guerrero E, Quintanilla-Cedillo MR, Ruiz-Esmenjaud J, Arenas R (2017) Leishmaniasis: a review. F1000Res; 6:750

69. Keramati MR, Khooei A, Aelami MH (2013) Visceral leishmaniasis with massive hematemesis and peripheral blood involvement. Clin Lab 59:425-427

70. Elsafi Ahmed Abdalla CEA, Ahmed AMF, ElGaddal ASA, Saeed A (2014) Ultrasound findings in patients with visceral leishmaniasis. International Journal of Medical Imaging 2:5

71. Bukte $Y$, Nazaroglu H, Mete A, Yilmaz F (2004) Visceral leishmaniasis with multiple nodular lesions of the liver and spleen: CT and sonographic findings. Abdom Imaging 29:82-84

72. Raeymaeckers S, Docx M, Demeyere N (2012) MRl-findings of nodular lesions in an enlarged spleen, associated with visceral Leishmaniasis. Eur J Radiol 81:2550-2553

73. Vassalou E, Vassalos CM, Spanakos G et al (2016) First report of Dientamoeba fragilis infection explaining acute non-specific abdominal pain. Indian J Med Microbiol 34:106-108

74. Yasunaga $H$, Horiguchi H, Kuwabara K, Hashimoto H, Matsuda S (2010) Clinical features of bowel anisakiasis in Japan. Am J Trop Med Hyg 83:104-105

75. Rodriguez Carnero P, Hernandez Mateo P, Martin-Garre S, Garcia Perez A, Del Campo L (2017) Unexpected hosts: imaging parasitic diseases. Insights Imaging 8:101-125

76. Shibata E, Ueda T, Akaike G, Saida Y (2014) CT findings of gastric and intestinal anisakiasis. Abdom Imaging 39:257-261

77. Lalchandani UR, Weadock WJ, Brady GF, Wasnik AP (2018) Imaging in gastric anisakiasis. Clin Imaging 50:286-288

78. Cwiklinski K, O'Neill SM, Donnelly S, Dalton JP (2016) A prospective view of animal and human Fasciolosis. Parasite Immunol 38:558-568

79. Gonzalo-Orden M, Millan L, Alvarez M et al (2003) Diagnostic imaging in sheep hepatic fascioliasis: ultrasound, computer tomography and magnetic resonance findings. Parasitol Res 90:359-364

80. Despommier D (2003) Toxocariasis: clinical aspects, epidemiology, medical ecology, and molecular aspects. Clin Microbiol Rev 16:265-272 
81. Chang S, Lim JH, Choi D et al (2006) Hepatic visceral larva migrans of Toxocara canis: CT and sonographic findings. AJR Am J Roentgenol 187: W622-W629

82. Lim JH (2008) Toxocariasis of the liver: visceral larva migrans. Abdom Imaging 33:151-156

83. Kuenzli E, Neumayr A, Chaney M, Blum J (2016) Toxocariasis-associated cardiac diseases--A systematic review of the literature. Acta Trop 154:107120

84. Kinoo SM, Ramkelawon W, Maharajh J, Singh B (2018) Fulminant amoebic colitis in the era of computed tomography scan: a case report and review of the literature. SA J Radiol 22:1354

85. Mortele KJ, Segatto E, Ros PR (2004) The infected liver: radiologic-pathologic correlation. Radiographics 24:937-955

86. Stark D, Barratt J, Chan D, Ellis JT (2016) Dientamoeba fragilis, the Neglected Trichomonad of the Human Bowel. Clin Microbiol Rev 29:553-580

87. Vandenberg O, Peek R, Souayah $\mathrm{H}$ et al (2006) Clinical and microbiological features of dientamoebiasis in patients suspected of suffering from a parasitic gastrointestinal illness: a comparison of Dientamoeba fragilis and Giardia lamblia infections. Int J Infect Dis 10:255-261

88. Schwartz MD, Nelson ME (2003) Dientamoeba fragilis infection presenting to the emergency department as acute appendicitis. J Emerg Med 25:17-21

\section{Publisher's Note}

Springer Nature remains neutral with regard to jurisdictional claims in published maps and institutional affiliations.

\section{Submit your manuscript to a SpringerOpen ${ }^{\circ}$ journal and benefit from:}

- Convenient online submission

- Rigorous peer review

- Open access: articles freely available online

High visibility within the field

- Retaining the copyright to your article

Submit your next manuscript at $\boldsymbol{\nabla}$ springeropen.com 